\title{
Safety Aspects of the Use of Isolated Piperine Ingested as a Bolus
}

\author{
Rainer Ziegenhagen, Katharina Heimberg, Alfonso Lampen and Karen Ildico Hirsch-Ernst *
}

Citation: Ziegenhagen, R.; Heimberg, K.; Lampen, A.; Hirsch-Ernst, K.I. Safety Aspects of the Use of Isolated Piperine Ingested as a Bolus. Foods 2021, 10, 2121. https://doi.org/10.3390/ foods10092121

Academic Editor: Dirk

W. Lachenmeier

Received: 13 August 2021

Accepted: 6 September 2021

Published: 8 September 2021

Publisher's Note: MDPI stays neutral with regard to jurisdictional claims in published maps and institutional affiliations.

Copyright: (c) 2021 by the authors. Licensee MDPI, Basel, Switzerland. This article is an open access article distributed under the terms and conditions of the Creative Commons Attribution (CC BY) license (https:// creativecommons.org/licenses/by/ $4.0 /)$.
German Federal Institute for Risk Assessment (BfR), Max-Dohrn-Str. 8-10, 10589 Berlin, Germany; rainer.ziegenhagen@bfr.bund.de (R.Z.); Katharina.Heimberg@bfr.bund.de (K.H.); Alfonso.Lampen@bfr.bund.de (A.L.)

* Correspondence: Karen-Ildico.Hirsch-Ernst@bfr.bund.de

\begin{abstract}
Piperine is a natural ingredient of Piper nigrum (black pepper) and some other Piper species. Compared to the use of pepper for food seasoning, piperine is used in food supplements in an isolated, concentrated form and ingested as a bolus. The present review focuses on the assessment of the possible critical health effects regarding the use of isolated piperine as a single ingredient in food supplements. In human and animal studies with single or short-term bolus application of isolated piperine, interactions with several drugs, in most cases resulting in increased drug bioavailability, were observed. Depending on the drug and extent of the interaction, such interactions may carry the risk of unintended deleteriously increased or adverse drug effects. Animal studies with higher daily piperine bolus doses than in human interaction studies provide indications of disturbance of spermatogenesis and of maternal reproductive and embryotoxic effects. Although the available human studies rarely reported effects that were regarded as being adverse, their suitability for detailed risk assessment is limited due to an insufficient focus on safety parameters apart from drug interactions, as well as due to the lack of investigation of the potentially adverse effects observed in animal studies and/or combined administration of piperine with other substances. Taken together, it appears advisable to consider the potential health risks related to intake of isolated piperine in bolus form, e.g., when using certain food supplements.
\end{abstract}

Keywords: piperine; food safety; drug interaction; reproductive toxicity; bolus administration

\section{Introduction}

The alkaloid piperine ((E,E)-piperine; IUPAC-name: (2E,4E)-5-(2H-1,3-benzodioxol-5yl)-1-(piperidin-1-yl)penta-2,4-dien-1-one; CAS-No.: 94-62-2; FEMA-No: 2909; molecular formula: $\mathrm{C}_{17} \mathrm{H}_{19} \mathrm{NO}_{3}$; molecular weight: $285.34 \mathrm{~g} / \mathrm{mol}$ ) is a natural ingredient of Piper nigrum, Piper longum and some other Piper species, as well as of Aframomum melegueta K. Schum. (Grains of Paradise) [1-7]. The alkaloid is the main compound imparting the pungent flavour to fruits of Piper nigrum and Piper longum. Piper nigrum fruits are used to produce black, white and green pepper. Black peppercorns are produced from whole, dried, full-grown, not yet fully ripe fruits, while white peppercorns are produced from dried, ripe fruits after removal of the outer layer [8,9]. Green peppercorns are obtained from unripe fruits subjected to processing methods by which the green colour is maintained.

The occurrence of piperine in the European/Western diet primarily results from use of pepper for food seasoning, but also from the use of the substance in isolated form for spicing/flavouring purposes, e.g., in beverages and spirits [2]. The substance can occur in four stereoisomeric forms: (E,E)-piperine (= piperine), $(Z, E)$-piperine (= isopiperine), $(\mathrm{E}, \mathrm{Z})$-piperine (= isochavicine) and $(\mathrm{Z}, \mathrm{Z})$-piperine (= chavicine). In black and white pepper, (E,E)-piperine constitutes by far the main and most pungent isomer. The other three isomers seem to be formed primarily via light-induced or enzymatic isomerization [10]. 
Primarily in in vitro and in animal studies, as well as in some human studies, piperine has been shown to be a biologically versatile compound that can interact with a variety of chemically and functionally diverse biomolecular targets, such as enzymes, membrane transporters, receptors or other biomolecules. For example, piperine may provide protection against forms of oxidative damage and improve the activities of compromised anti-oxidative defence mechanisms (e.g., related to superoxide dismutase or catalase), but depending on the study settings, may also decrease the anti-oxidative defence mechanisms and among others, piperine further displays the potential to influence the activity of drugmetabolizing enzymes, including enzymes involved in phase I (cytochrome P-450-enzymes) and phase II metabolism (e.g., UDP-glucuronosyltransferases), to interact with cellular drug transporters (e.g., P-glycoprotein) or to modulate the cellular targets (monoamine oxidase) associated with neurodegenerative diseases [1,11-18].

Currently, attention is largely focused on the potential of piperine to influence the bioavailability of certain drugs via interaction with drug-metabolizing enzymes and/or inhibition of drug transporters or efflux pumps, thereby in many cases increasing the drug bioavailability and efficacy. In addition, inclusion of piperine into drug-loaded nanoparticles or lipospheres is being investigated as a means of increasing the effectiveness of advanced drug delivery systems [19,20].

In food supplements, piperine (primarily in the form of highly piperine-enriched pepper extracts, frequently with a piperine content in the range of $\geq 95 \%$ ) is often used and promoted, among others, as a bio-enhancer to increase the bioavailability of other ingredients contained in these food supplements. Based on the use of piperine in various food supplements, its multi-facetted biological activities, and on the differences regarding the pattern of piperine intake when comparing the use of food supplements to the use of pepper for food seasoning, a closer look into the safety aspects of the use of piperine as an ingredient of food supplements appears to be warranted.

This review focuses on the possible critical health effects regarding the use of isolated piperine as a single ingredient in food supplements (i.e., without the addition of other bioactive substances). The use of isolated piperine as a flavouring agent is outside the scope of this review. In the context of the present review, the focus was laid on adult persons; thus, children and adolescents were not considered. To this end, a literature search was performed in the scientific databases Pubmed and Embase, with the last update performed in February 2021. To initially retrieve a broad spectrum of references, the search term "piperine" was used, without combination with other search terms. To further identify the relevant scientific publications that are within the scope of the present review, the abstracts of the retrieved references were screened to facilitate the selection of a subset of publications that were subsequently subjected to further scrutiny of the full texts. In addition, reference lists of the identified relevant publications as well as websites of acknowledged scientific bodies or national authorities were checked.

\section{Occurrence and Exposure}

\subsection{Occurrence}

Piper nigrum is the main source of piperine in European/Western cuisine. Other potential sources are foods flavoured with piperine in isolated form or foods flavoured with other Piper species (e.g., Piper longum and Piper retrofractum Vahl)or with the spice "grains of paradise" (Aframomum melegueta) [2]. Regarding the piperine content of black pepper, ranges of $2-7 \%$ [21], 2-9\% [13] or 4-6\% with contents up to $10 \%$ [2] have been reported. For Piper longum, piperine contents of 1.2-5\% [13,22-24], and for Piper retrofractum Vahl contents of $3.1-4.5 \%$ have been indicated $[13,23]$. In an investigation of four commercial brands of pure ground black pepper with high piperine contents (10-11\%), E,E-piperine was the most abundant ( $\geq 99 \%$ of detected piperine isomers) and Z,Z-piperine (= chavicine) the least abundant $(\leq 0.07 \%)$ piperine isomere [10].

During storage of ground black, white and green pepper at $4{ }^{\circ} \mathrm{C}$ for 6 months, a decrease in piperine content of about $12-30 \%$ was observed [25]. Different findings were made 
regarding heat treatment of pepper, ranging from mild piperine losses of 4-12.5\% during cooking in an open pan (30 $\mathrm{min}$ ) or pressure cooking (20 $\mathrm{min}$ ) [26] to losses of approximately $28 \%$ during cooking ( $20 \mathrm{~min}$ ) or about $34 \%$ during pressure cooking (10 $\mathrm{min}$ ) [27].

\subsection{Exposure}

In 2007, by extrapolation from limited consumption data, the Australian Therapeutic Goods Administration (TGA) estimated that the piperine intake in New Zealand was about $25 \mathrm{mg}$ per person per day, in the USA approximately $60 \mathrm{mg}$ and in India approximately $120 \mathrm{mg}$ per person per day [28]. According to another source, which was based on annual US import data of black pepper, with an estimated average per capita intake of approximately $0.7 \mathrm{~g}$ pepper/day, a corresponding per capita piperine intake of $14-54 \mathrm{mg}$ /day was calculated for the US population [29].

In an exposure estimation performed by the German Federal Institute for Risk Assessment (BfR) in 2018, which was based on food consumption data from the National Consumption Survey II of the Max Rubner-Institute (2008) [30], including approximately 20,000 individuals, a mean per capita pepper intake of the male German population (14-80 years) of $0.6 \mathrm{~g} /$ day was estimated, with an estimated per capita intake at the 95th intake percentile of $1.6 \mathrm{~g}$ pepper/day. Assuming an average piperine content in pepper of 4-6\%, this would correspond to an estimated mean per capita intake by the male population of 24-36 mg piperine/day and an estimated intake at the 95th percentile of $64-96 \mathrm{mg}$ piperine/day. Regarding this estimation, it is noted on the one hand that information on the consumption of herbs/spices is generally subject to greater uncertainty as their consumption is often not documented, and an underestimation of the amount consumed can therefore be assumed. On the other hand, it should be borne in mind that this intake estimation does not take into account possible piperine losses caused by storage or food preparation.

In India, a consumption survey conducted from December 2006 to July 2008 in three regions recorded the median monthly per capita intakes of black pepper of 3-18.5 g (0.1-0.62 g/day) and in the 90th percentile of $16.7-41.7 \mathrm{~g}(0.56-1.39 \mathrm{~g} /$ day) [31]

Taken together, the available estimations of daily piperine intake resulting from the use of pepper in food preparation are afflicted with considerable scientific uncertainty. It should also be kept in mind that when using pepper for food seasoning, the piperine intake occurs in conjunction with all other pepper constituents and with different degrees of comminution of the peppercorn, potentially bringing about matrix effects influencing the bioavailability or pharmacodynamic effects of piperine ingested in this way, which may differ from the intake of piperine as an isolated substance.

In its assessment of isolated piperine and several aliphatic and arylalkyl amines and amides as flavouring agents, the European Food Safety Authority EFSA (2015) reported an estimated European per capita intake of $6.2 \mu \mathrm{g}$ piperine/day for the use of isolated piperine as a flavouring substance based on the EU Maximised Survey-derived Daily Intake (MSDI) method (see also below). However, EFSA noted in this assessment that the use levels were needed for some of the abovementioned flavouring substances, including piperine, to calculate the Modified Theoretical Added Maximum Daily Intakes (mTAMDIs) in order to identify those flavouring substances that required a more refined exposure assessment and to finalise the evaluation [32].

In food supplements, piperine is usually used in combination with other ingredients to increase their bioavailability, and commonly its addition occurs via highly piperineenriched black pepper extracts (piperine content frequently in the range of $\geq 95 \%$ ). Therefore, black pepper extract is often mentioned on the ingredient list of food supplements and the piperine content is only indicated in second place. The piperine content of food supplements is frequently in the range of $5-30 \mathrm{mg}$ per daily dose, with single products reaching dosages of 40 or up to about $50-100 \mathrm{mg}$ per daily dose, but the market may be subject to change. 
The piperine content of the highly piperine-enriched black pepper extracts (frequently in the range of $\geq 95 \%$ ) is very similar to the piperine content of chemically defined piperine used as an isolated flavouring substance (piperine content $\geq 97 \%$ [33]) or to the piperine content of the substance used in scientific investigations, for which it was procured as a chemical from chemical companies (usually $\geq 97 \%$ ).

\section{Kinetics and Metabolism}

In animal studies conducted by Bhat and Chandrasekhara [34,35] and Suresh and Srinivasan [36], with rats receiving an oral dose of $170 \mathrm{mg}$ piperine/ $\mathrm{kg}$ body weight (bw), only about $3-4 \%$ of the dose was detected in faeces in unchanged form over a period of 4 or 5 days, respectively, and it was concluded that $96-97 \%$ of the administered piperine dosage was absorbed $[34,36]$. In an accompanying investigation with everted sacs of rat intestines, only piperine was detected in serosal fluid and intestinal tissue, which led to the conclusion that piperine did not undergo any metabolic change during absorption [34]. However, in both the abovementioned animal studies, only small portions of the administered oral dose could be detected in serum and investigated tissues. In the more recent study of Suresh and Srinivasan (2010), maximum levels were reached $6 \mathrm{~h}$ after oral administration of a piperine dose of $170 \mathrm{mg} / \mathrm{kg}$ bw, with approximately $38.8 \mu \mathrm{mol}$ piperine/L in serum and $0.39 \%$ of the administered piperine dose in liver, $0.37 \%$ in kidney and about $9.7 \%$ in the flushed intestine [36]. In both studies, no piperine was detectable in urine [34,36], but Bhat and Chandrasekhara detected piperine metabolites, i.e., piperonylic acid, piperonyl alcohol, piperonal and vanillic acid, and their conjugates, in urine, which in their free forms represented about $15.5 \%$ of the administered dose (measured within $96 \mathrm{~h}$ after piperine administration) [35]. The latter authors assumed that most of the administered piperine was absorbed and that it was not transformed during intestinal absorption but was probably later metabolized rapidly by other tissues [34].

In a more recent study in rats, the bioavailability of an oral dose of $3.5 \mathrm{mg}$ piperine $/ \mathrm{kg}$ bw was calculated to be about $25 \%$ by comparing plasma AUC values following oral and i.v. administration [37]. Regarding piperine metabolites, Gao et al. (2017) identified 12 metabolites in rat plasma, bile, urine and faeces, with 10 piperine metabolites occurring both in plasma and urine. The metabolites were grouped into metabolites resulting from methylenedioxycyclic ring-opening, from methylenedioxycyclic ring-oxidation and from piperidine ring-cleavage [38]. Shang et al. (2017) even detected and tentatively characterized 148 piperine metabolites in rat plasma, urine and faeces after oral administration of $250 \mathrm{mg}$ piperine/kg bw. Piperine mainly underwent hydrogenation, dehydrogenation, hydroxylation, glucuronide conjugation, sulphate conjugation, ring cleavage and their composite reactions. However, information on plasma or urine levels of the detected piperine metabolites is not available from this study [39]. In laying hens receiving piperine-enriched feed ( $80 \mathrm{mg} / \mathrm{kg}$ feed), significant proportions of piperine isomers were observed in egg yolks (3.0 $\mu \mathrm{g}$ piperine, $0.7 \mu \mathrm{g}$ chavicine, $2.9 \mu \mathrm{g}$ isopiperine and $5.3 \mu \mathrm{g}$ isochavicine per $\mathrm{g}$ egg yolk), indicating that piperine metabolism can also comprise substance isomerization [40].

Information on piperine serum or plasma levels observed in rats after oral administration is not uniform. With oral doses of 3.5, 20,35 or $250 \mathrm{mg}$ piperine $/ \mathrm{kg}$ bw, corresponding plasma $C_{\max }$ values of approximately $0.45,3.4,5.4-6.0$ or $12.7 \mu \mathrm{mol}$ piperine/L were observed in different studies [37,41-43]. However, other studies observed higher $\mathrm{C}_{\max }$ values with approximately $9.9 \mu \mathrm{mol} / \mathrm{L}$ after an oral dose of $20 \mathrm{mg}$ piperine $/ \mathrm{kg}$ bw [44] or levels of approximately $28-39 \mu \mathrm{mol} / \mathrm{L}$ after a dose of $170 \mathrm{mg}$ piperine/ $\mathrm{kg}$ bw [34,36]. Plasma protein binding was about $98 \%$ in rats receiving an oral dose of $35 \mathrm{mg}$ piperine $/ \mathrm{kg}$ bw [42]. Furthermore, piperine was shown to efficiently penetrate and homogeneously distribute into the brain of rats after oral piperine doses (35 $\mathrm{mg} / \mathrm{kg} \mathrm{bw})$, leading to comparable $\mathrm{AUC}_{(0-\infty)}$-values in brain and plasma with a brain-plasma AUC ratio of 0.95 . However, based on the $\mathrm{AUC}_{(0-\infty)}$ values, the piperine level in cerebrospinal fluid was around 50 times lower than in brain or plasma [42]. 
In humans, information on kinetics and metabolism of oral piperine doses are sparse. In an investigation with two individuals receiving a single oral dose of $50 \mathrm{mg}$ piperine (approximately $0.71-0.83 \mathrm{mg} / \mathrm{kg}$ bw, assuming a body weight of $60-70 \mathrm{~kg}$ ), the plasma peak concentrations reached 2.7-3.3 $\mu \mathrm{mol} / \mathrm{L}\left(\mathrm{T}_{\max }=1-3 \mathrm{~h}\right)$ [45].

In human urine, the piperine metabolites 5-(3-4-dihydroxphenyl)valeric acid piperidide (which was excreted as sulphate) and its derivate hydroxylated in position 4 of the piperidine ring, 5-(3-4-dihydroxphenyl)valeric acid-4-hydroxypiperidide, were observed one or two days after oral administration of piperine $(25 \mathrm{mg})$ or a high dose of pepper, respectively. Interestingly, these two urine metabolites could not be detected in 2 out of 14 investigated individuals who instead excreted 5-(3-4-dihydroxphenyl)-2-4-pentadienoic acid piperidide, providing first indications for individual differences in human piperine metabolism [46]. In rat urine, all three metabolites could be detected [38]. In an in vitro study comparing the hepatic piperine metabolism in mouse, rat, dog and human hepatocytes, the predominant metabolic pathways included formation of a catechol derivate for all species; however, the metabolic pathways displayed species-specific differences in terms of types and quantities of metabolites [47].

\section{Safety Aspects}

\subsection{Information Based on Evaluations by Scientific Bodies and National Authorities}

The European Food Safety Authority (EFSA) has evaluated the use of piperine as a flavouring substance. In its evaluations, EFSA $(2008 ; 2011 ; 2015)$ disagreed with a No Observed Effect Level (NOEL) of $20 \mathrm{mg}$ piperine $/ \mathrm{kg}$ bw/day that had previously been identified by the Joint FAO/WHO Expert Committee on Food Additives (JECFA) (2006), due to the shortcomings of the underlying animal study (lack of histopathology, study duration) and in 2015 identified a No Observed Adverse Effect Level (NOAEL) of $5 \mathrm{mg}$ piperine/ $\mathrm{kg}$ bw/day, based on a newly available 90-day rat feeding study performed according to OECD guideline 408 (endpoint: dose-dependent increase in cholesterol level in male animals) [29,32,48-50] (see (2) in Section 4.2.2). In its final conclusion, EFSA (2015) agreed with the JECFA (2006) conclusion "no safety concern at estimated levels of intake as flavouring substance" based on the MSDI approach (estimated European per capita intake by the MSDI approach: $6.2 \mu \mathrm{g}$ piperine/day) [32,50]. Currently, isolated piperine is approved as a flavouring agent in the European Union with no restrictions on use or maximum levels set in regulation (EC) No. 1334/2008. However, its use level may be self-limiting due to the pungent taste of piperine.

In 2007, the Australian Complementary Medicines Evaluation Committee (CMEC) evaluated the use of piperine as a component in herbal preparations for use in listed medicines. Due to the possible effects on the bioavailability of medicinal products (leading to increased bioavailability in most cases, see Section 4.2.4) and the risk of inadvertent interactions with medicinal products, the committee recommended a maximum daily dose limit of $10 \mathrm{mg} /$ day for piperine (based on a person's body weight of $50 \mathrm{~kg}$ ) when present as a component in herbal preparations for use in listed medicines [28].

The Canadian authority Health Canada (2019) has elaborated a monograph on the use of Piper nigrum (black pepper) as an ingredient in Natural Health Products, which also includes piperine isolated from the fruits of Piper nigrum. For adults ( $\geq 18$ years), a daily dose of $250-420 \mathrm{mg}$ for the unextracted powder of Piper nigrum fruits and a daily maximum dose of $14 \mathrm{mg}$ for the use of piperine as an isolated substance in these products were established. For these products, a label statement is required that persons taking other medicines or natural health products should consult a healthcare practitioner/provider/professional or physician before use, as black pepper/piperine may alter their effectiveness. The same applies to pregnant or breastfeeding women. The monograph does not list any contraindications or known adverse reactions [51].

None of the evaluations described above mentioned the paternal reproductive toxicological effects observed in some animal studies (see (3) in Section 4.2.2). 
In 2016, on request of the Norwegian Food Safety Authority, the Norwegian Scientific Committee for Food Safety (VKM) carried out a risk assessment of a daily dose of $1.5 \mathrm{mg}$ piperine in food supplements. The panel applied the Margin of Exposure (MOE) approach in its assessment and used the NOAEL of $5 \mathrm{mg} / \mathrm{kg}$ bw/day identified by EFSA (2015), which was based on an animal study (endpoint: dose-dependent increase in cholesterol level in male animals) as the starting point for the MOE calculation. As the margin of exposure for all age groups considered was greater than 100, the panel concluded that this intake was unlikely to produce adverse effects in individuals aged 10 years or older [2].

\subsection{Potential Hazards \\ 4.2.1. Genotoxicity}

In its assessment of piperine as a flavouring agent, JECFA (2006) concluded regarding genotoxicity that piperine belongs to a group of aliphatic and aromatic amine and amide derivates for which negative results were reported in bacterial assays for reverse mutation and that piperine consistently gave negative results in a variety of in vivo studies [50,52-54]. EFSA agreed in its assessment with JECFA that the available studies on genotoxicity did not preclude the evaluation of piperine (and some other aliphatic and arylalkyl amines and amides) as a flavouring agent $[32,48,49]$.

In a more recent study, piperine displayed negative results in an in vitro micronucleus test with Chinese hamster ovary cells in the presence or absence of metabolic activation and caused no increase in the numbers of micronucleated polychromatic erythrocytes in an in vivo micronucleus test in mice with all the tested doses (highest tested dose $574 \mathrm{mg} / \mathrm{kg} \mathrm{bw}$ ), leading to the conclusion that in this study piperine was not genotoxic [55].

\subsubsection{Animal Studies}

\section{(1) Acute and Subacute Toxicity}

Piyachaturawat et al. investigated the acute toxicity of piperine (dissolved in equal volumes of DMSO and 95\% ethanol) following a single administration via intragastric (i.g.) gavage to mice and rats [56]. For adult male mice, the resulting calculated $\mathrm{LD}_{50}$ value was $330 \mathrm{mg} / \mathrm{kg}$ bw, compared to an $\mathrm{LD}_{50}$ of $15.1 \mathrm{mg} / \mathrm{kg}$ bw based on i.v. administration. In the same study, an $\mathrm{LD}_{50}$ value of $514 \mathrm{mg} / \mathrm{kg}$ bw was derived for single i.g. administration of piperine to adult female rats, while a higher $\mathrm{LD}_{50}$ value was calculated for young female weanling rats $\left(\mathrm{LD}_{50}>585 \mathrm{mg} / \mathrm{kg} \mathrm{bw}\right)$. Animals receiving lethal doses experienced convulsion and died of respiratory paralysis [56].

In another study with mice, all animals survived oral doses of 143 to $574 \mathrm{mg} / \mathrm{kg} / \mathrm{day}$ given on two consecutive days, but displayed lethargy ranging from a slight degree in the low-dose group to a severe one in the high-dose group [55].

In a subacute oral toxicity study with female rats receiving 0,100, 250, 350 or $500 \mathrm{mg}$ piperine $/ \mathrm{kg}$ bw/day for seven days, the body weight gain of animals receiving $100 \mathrm{mg} / \mathrm{kg}$ bw was comparable to that of the control group. Daily doses of $250 \mathrm{mg} / \mathrm{kg}$ bw led to reduced body weight gain and caused haemorrhage in the stomach of 3 out of 8 animals, whereas the higher doses of 350 and $500 \mathrm{mg} / \mathrm{kg}$ bw caused the death of 2 and 5 out of 8 animals, respectively. Animals receiving $500 \mathrm{mg}$ piperine $/ \mathrm{kg} \mathrm{bw} /$ day displayed histopathological changes of different types and degrees in the stomach, urinary bladder, adrenal glands and small intestine. In addition, luteal cells in the central portion of the corpora lutea were degenerated in this dosage group [56].

\section{(2) Subchronic Toxicity Studies}

In a study with groups of young male rats that received $100 \mathrm{mg}$ piperine $/ \mathrm{kg}$ feed for 56 days or 110, 220 or $440 \mathrm{mg}$ pepper oleoresin/ $\mathrm{kg}$ feed (equivalent to 50-200 $\mathrm{mg}$ piperine/kg feed), or $2 \mathrm{~g}$ pepper/ $\mathrm{kg}$ feed, no adverse effects on growth, food efficacy, organ weights, blood count and investigated clinical chemistry parameters were observed compared to the control group [50,57]. In its evaluation of piperine as a flavouring agent, JECFA (2006) based its NOEL for piperine of $20 \mathrm{mg} / \mathrm{kg}$ bw/day on this animal study, but 
EFSA (2008) considered this study inadequate for NOAEL identification due to studydesign limitations $[48,50]$. It should be mentioned that this animal study reported increased haemoglobin values for the piperine group $(242 \mathrm{~g} / \mathrm{L})$ compared to the control and to the pepper/pepper oleoresin groups $(\sim 140 \mathrm{~g} / \mathrm{L})$; however, the red blood cell count was similar to the other groups, making a typing error highly possible [57].

The subchronic toxicity study (90-day study) in rats that was finalised in 2013 and used by EFSA (2015) [32] for the assessment of piperine as a flavouring agent has been published meanwhile (Bastaki et al. (2018) [29]). In this study, 0, 5, 15 or $50 \mathrm{mg}$ piperine/ $\mathrm{kg}$ bw/day were administered via feed for 90 days. According to the EFSA assessment, the reduced weight gain observed in the highest male dose group was due to reduced feed intake (possibly related to food palatability). There were no mortalities, no gross and microscopic changes nor clinical pathology or organ weight changes attributable to piperine. Some statistically significant changes in haematology, coagulation or clinical chemistry parameters were considered by EFSA as not dose-dependent, small in magnitude and within the range of historical values. However, statistically significant dose-dependent increases in cholesterol levels were observed in male animals receiving 15 and $50 \mathrm{mg}$ piperine/ $\mathrm{kg}$ bw/day (approximately by 30 and $55 \%$, respectively), which was used by EFSA for NOAEL identification.

According to EFSA, reduced relative epididymides weights were observed in male animals administered 5 and $50 \mathrm{mg} / \mathrm{kg}$ bw/day, respectively, but these changes were considered small and not dose-dependent and therefore of limited toxicological relevance [32]. Regarding this finding, it is noted on the one hand that reduced relative (to-brain weight) epididymis weights (17-23\%) were observed in all three piperine dosage groups without displaying dose dependence, with reductions being statistically significant only in the 5 and $50 \mathrm{mg} / \mathrm{kg}$ bw dosage groups. On the other hand, it must be mentioned that these changes were without histopathological findings. From this study, EFSA identified a NOAEL of $5 \mathrm{mg}$ piperine $/ \mathrm{kg} \mathrm{bw} /$ day due to the dose-dependent elevated cholesterol plasma levels in male animals at the mid and high dose ( 15 and $50 \mathrm{mg} / \mathrm{kg}$ bw/day) [32].

Contrary to the EFSA (2015) assessment, Bastaki et al. (2018) ascribed no toxicological relevance to the observed increases in cholesterol levels described above because, in their opinion, the cholesterol levels were within the historical control range for male animals and because of corroborating evidence from other studies showing an absence of a cholesterol increase. Rather, they identified a NOAEL of $50 \mathrm{mg}$ piperine/ $\mathrm{kg}$ bw/day (the highest dose tested) from this study [29].

\section{(3) Paternal Reproductive Toxicological Effects}

In 1999, as a consequence of administration of 0,5 or $10 \mathrm{mg}$ piperine $/ \mathrm{kg}$ bw/day (suspended in $0.9 \%$ saline) via a gastric catheter to young adult male rats for 30 days ( $\mathrm{n}=10$ per group), Malini et al. $[58,59]$ reported in the high-dose group statistically significantly $(p<0.05)$ reduced sperm concentrations in caput and cauda epididymides, statistically significantly reduced relative weight of testis (relative to body weight) and reduced absolute weight of the cauda epididymides, vas deferens, seminal vesicle and ventral prostate. The relative organ weights were also reduced, according to the authors' own calculations based on the mean body and organ weights stated in one of the two publications by Malini et al. [59]; however, no information on statistical significance is available for these calculations. Furthermore, histopathological changes in the testis, increased serum gonadotropins (FSH, LH) and reduced the intra-testicular testosterone concentration, as well as reduced the testicular lipid content, changes in the testicular lipid profile and reduced activity of some testicular lipogenic enzymes were observed (for details, see Table 1). Histopathological changes in the testes were also observed at $5 \mathrm{mg}$ piperine $/ \mathrm{kg}$ bw/day, but to a lesser extent than in the high-dose group. Within this low-dose group, the other parameters mentioned above showed changes in the same direction as seen in the high-dose group, but these changes were also of smaller magnitude and, in the majority of cases, no longer statistically significant. The reduced testicular weight was attributed to disturbed spermatogenesis and the reduced total lipid content of the testes caused by piperine administration [58,59]. 
Table 1. Paternal reproductive effects of piperine observed in animal studies.

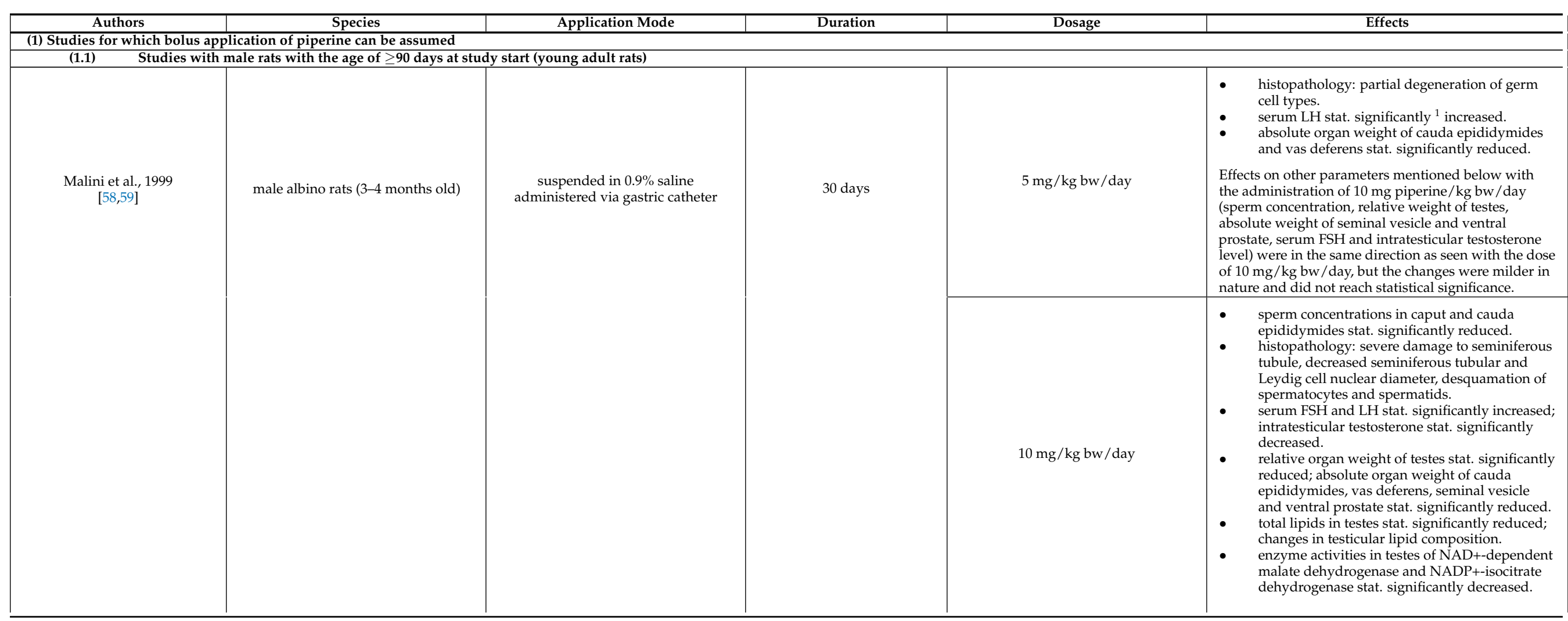


Table 1. Cont.

\begin{tabular}{|c|c|c|c|c|c|}
\hline Authors & Species & Application Mode & Duration & Dosage & Effects \\
\hline \multirow[t]{3}{*}{$\begin{array}{l}\text { D'Cruz and Mathur, 2005; and } \\
\text { D'Cruz et al., } 2008[60,61]\end{array}$} & \multirow[t]{3}{*}{ male Wistar rats (90 days old) } & \multirow[t]{3}{*}{$\begin{array}{l}\text { dissolved in vehicle }(10 \% \text { DMSO in } \\
\text { ethanol and groundnut oil ration of } \\
1: 1) \text { administered via micropipette }\end{array}$} & \multirow[t]{3}{*}{30 day } & $1 \mathrm{mg} / \mathrm{kg} \mathrm{bw} /$ day & $\begin{array}{l}\text { - no relevant effects on sperm parameters, } \\
\text { weight of testes and accessory sex organs or } \\
\text { investigated enzyme activities. }\end{array}$ \\
\hline & & & & $10 \mathrm{mg} / \mathrm{kg}$ bw/day & $\begin{array}{l}\text { - } \quad \text { stat. significantly decreased epididymal sperm } \\
\text { count and sperm motility. } \\
\text { stat. significantly reduced absolute organ } \\
\text { weight of testes and caput, corpus and cauda } \\
\text { epididymides. } \\
\text { stat. significantly reduced levels of sialic acid in } \\
\text { testes and caput epididymides. } \\
\text { reduced activity of antioxidant enzymes in } \\
\text { testes and corpus and cauda epididymides (in } \\
\text { most cases statistically significant). } \\
\text { stat. significantly increased hydrogen peroxide } \\
\text { generation in testes and corpus and cauda } \\
\text { epididymides. }\end{array}$ \\
\hline & & & & $100 \mathrm{mg} / \mathrm{kg}$ bw and day & $\begin{array}{l}\text { - } \quad \text { stat. significantly decreased epididymal sperm } \\
\text { count, sperm motility and sperm viability. } \\
\text { significantly reduced relative organ weight of } \\
\text { testes (as indicated in text, data not shown); } \\
\text { stat. significantly reduced absolute organ } \\
\text { weight of caput, corpus, cauda epididymides, } \\
\text { seminal vesicle and ventral prostate. } \\
\text { stat. significantly reduced levels of sialic acid in } \\
\text { testes and caput, corpus and cauda } \\
\text { epididymides, coduct activity of } \\
\text { stat. significantly reduced actide } \\
\text { antioxidant enzymes in testes and } \\
\text { epididymides. } \\
\text { stat. significantly increased hydrogen peroxide } \\
\text { generation in testes and caput, corpus and } \\
\text { cauda epididymides. }\end{array}$ \\
\hline
\end{tabular}


Table 1. Cont

\begin{tabular}{|c|c|c|c|c|c|}
\hline Authors & Species & Application Mode & Duration & Dosage & Effects \\
\hline \multirow[t]{3}{*}{$\begin{array}{l}\text { Chinta and Periyasamy 2016; } \\
\text { and Chinta et al., } 2017[16,62]\end{array}$} & \multirow[t]{3}{*}{$\begin{array}{l}\text { male Wistar rats } \\
\text { (90 days old) }\end{array}$} & \multirow[t]{3}{*}{$\begin{array}{c}\text { suspended in } 0.5 \% \text { carboxymethyl } \\
\text { cellulose (no further information on } \\
\text { application mode) }\end{array}$} & \multirow[t]{3}{*}{$\begin{array}{l}60 \text { days of piperine } \\
\text { administration followed by } \\
\text { recovery period of } 60 \text { days } \\
\text { without piperine } \\
\text { administration }\end{array}$} & $\begin{array}{c}10 \mathrm{mg} / \mathrm{kg} \text { bw administered } \\
\text { every day }\end{array}$ & $\begin{array}{l}\text { Effects at the end of the piperine administration period }{ }^{2} \\
\text { - } \quad \text { stat. significantly decreased epididymal sperm count, sperm motility } \\
\text { and sperm viability. } \\
\text { histopathology: desquamated spermatozoa and decreased thickness } \\
\text { of germ layer in seminiferous tubules; histopathological changes in } \\
\text { epididymides and seminal vesicle. } \\
\text { - } \quad \text { serum FSH, LH and sex hormone-binding globulin stat. significantly } \\
\text { increased; testicular testosterone stat. significantly decreased. } \\
\text { - stat. significantly reduced level of sialic acid in epididymides and } \\
\text { fructose level in seminal vesicles, } \\
\text { stat. significantly reduced activity of antioxidant enzymes (super } \\
\text { oxide dismutase, catalase) in testes and epididymides. } \\
\text { stat. significantly increased lipid peroxidation in testes and } \\
\text { - epidydimides. } \\
\text { in Leydig cells stat significantly decreased activity of enzymes } \\
\text { involved in testosterone synthesis } \\
\text { absolute liver weight was reduced by approximately } 36 \% \text { (stat. } \\
\text { significant) } \\
\text { After a recovery period of } 60 \text { days without piperine administration, the } \\
\text { observed adverse effects on reproductive organs were reversible } \\
\text { Absolute liver weight was still reduced by approximately } 29 \% \text { (stat. not } \\
\text { significant). }\end{array}$ \\
\hline & & & & $\begin{array}{c}10 \mathrm{mg} / \mathrm{kg} \text { bw administered } \\
\text { every } 4 \text { th day }\end{array}$ & $\begin{array}{l}\text { Effects at the end of the piperine administration period }{ }^{2} \\
\text { - With this administration regime, several of the adverse effects seen } \\
\text { with the daily piperine administration were also observed but these } \\
\text { changes were smaller, however, in some cases still statistically } \\
\text { significant: } \\
\text { (i.e., stat significantly reduced sperm motility and viability; } \\
\text { stat significantly reduced testicular testosterone; } \\
\text { stat significantly reduced levels of sialic acid in epididymides and fructose } \\
\text { in seminal vesicle; } \\
\text { stat significantly reduced activity of antioxidant enzymes in epididymides). } \\
\text { Some other changes did not reach statistical significance. } \\
\text { - Absolute liver weight was reduced by approximately } 35 \% \text { (stat } \\
\text { significant). } \\
\text { After a recovery period of } 60 \text { days without piperine administration the } \\
\text { observed adverse effects on reproductive organs were reversible with no } \\
\text { significant deviations from control group. } \\
\text { Absolute liver weight was still reduced }\end{array}$ \\
\hline & & & & $\begin{array}{c}10 \mathrm{mg} / \mathrm{kg} \mathrm{bw} \text { administered } \\
\text { every } 7 \text { th day }\end{array}$ & $\begin{array}{l}\text { Effects at the end of the piperine administration period } \\
\text { - Sperm count or testicular testosterone were somewhat reduced but } \\
\text { without reaching statistical significance. } \\
\text { Absolute liver weight was reduced by approximately } 39 \% \text { (stat. } \\
\text { significant). } \\
\text { After a recovery period of } 60 \text { days without piperine administration, no } \\
\text { significant deviations from control group }\end{array}$ \\
\hline
\end{tabular}


Table 1. Cont.

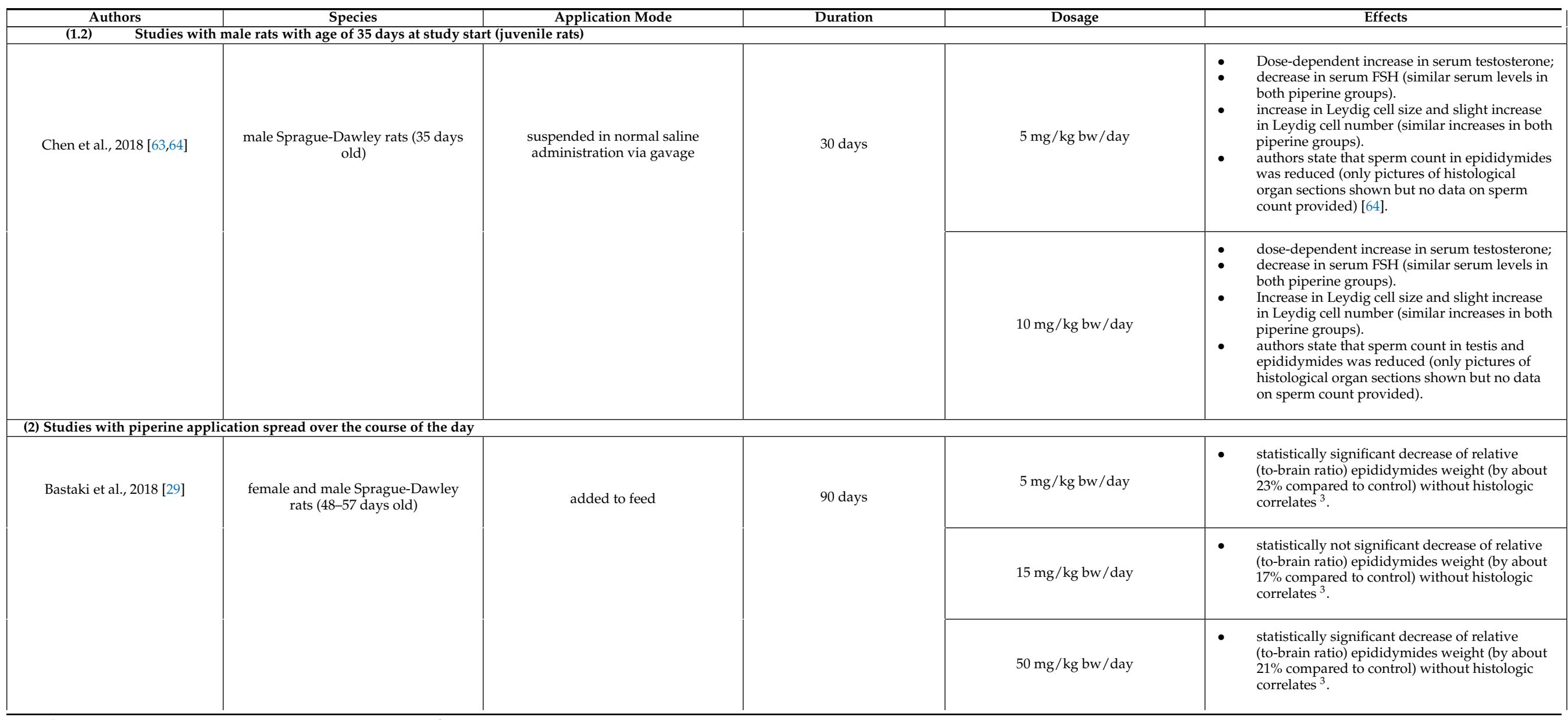

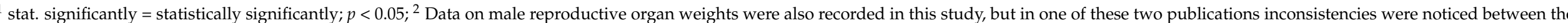

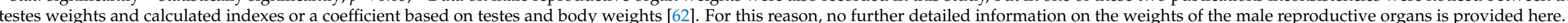
Only potentially reprotoxicologically relevant effects reported. For other effects observed in this study, see (2) in Section 4.2.2. 
In another study [60], D'Cruz and co-workers administered 0, 1, 10 and $100 \mathrm{mg}$ piperine $/ \mathrm{kg} \mathrm{bw} /$ day dissolved in a vehicle (10\% DMSO in ethanol and groundnut oil at the ratio of 1:1) to young adult male rats via a micropipette for 30 days and observed in the $10 \mathrm{mg} / \mathrm{kg}$ bw group statistically significant $(p<0.05)$ reductions in the cauda epididymal sperm count and sperm motility, statistically significantly reduced absolute weight of the testes and caput, corpus and cauda epididymides, and reduced activity of the antioxidant enzymes in the testes and corpus and cauda epididymides, accompanied by increased hydrogen peroxide generation and lipid peroxidation. In this study, the observed effects in the $10 \mathrm{mg} / \mathrm{kg}$ bw group on epididymal sperm count and testicular and epididymal weight were markedly smaller than in the study by Malini and co-workers. In the highdose group $(100 \mathrm{mg} / \mathrm{kg} \mathrm{bw})$, the effects were more pronounced and additionally included statistically significantly reduced sperm viability and significantly reduced relative testes weight (relative to body weight) (for details, see Table 1). Further immunofluorescence studies by the same group [61] revealed a dose-dependent increase in caspase 3 and FAS protein in testicular germ cells that was related to piperine administration and was accompanied by dose-dependent changes in the testicular antioxidant system (reduced activity of antioxidant enzymes, increases in hydrogen peroxide generation and in lipid peroxidation). In the low-dose group $(1 \mathrm{mg} / \mathrm{kg} \mathrm{bw})$, no relevant reproductive toxicological effects were observed in either of the studies by D'Cruz et al. [60,61]. These studies used small animal groups with only four animals each, which reduces the scientific significance of the study findings.

In young adult male rats that orally received $10 \mathrm{mg}$ piperine $/ \mathrm{kg}$ bw/day (suspended in normal saline containing $0.5 \%$ carboxymethyl cellulose) for 60 days, Chinta and coworkers observed a statistically significantly $(p<0.05)$ reduced epididymal sperm count, sperm motility and sperm viability compared to the control group (the latter receiving the vehicle only), accompanied by histopathological changes in the testes and epididymides; statistically significantly increased serum gonadotropins ( $\mathrm{FSH}, \mathrm{LH})$, with a reduced intratesticular testosterone concentration; and statistically significantly reduced activity of anti-oxidant enzymes or other enzymes in the testes and epididymides (for details, see Table 1) [16,62]. Data on reproductive organ weights were also recorded in this study, but in one of the two publications dealing with this study, inconsistencies were noticed between the testes weights and calculated indexes or a coefficient based on testes and body weights [62]. For this reason, no further detailed information on the weights of the reproductive organs is provided here. After a recovery period of 60 days without piperine administration, the observed changes were reversible.

Animals receiving the piperine dose $(10 \mathrm{mg} / \mathrm{kg} \mathrm{bw})$ every 4 th day in the same study displayed some of the abovementioned adverse effects that were also observed with the daily piperine administration, e.g., reduced sperm viability and mobility, which were less pronounced but in some cases still statistically significant (for details, see Table 1). With piperine administration $(10 \mathrm{mg} / \mathrm{kg} \mathrm{bw})$ every 7 th day, the individual parameters that were mentioned in relation to the daily piperine administration showed changes in the same direction but the changes were considerably milder and no longer statistically significant (e.g., sperm count, testicular testosterone). Chinta and co-workers concluded from their data that piperine might be a good lead molecule for the development of a reversible oral male contraceptive [16,62]. Animals receiving piperine every day displayed decreased body weight of about $10 \%$ after 60 days of piperine administration, which was not statistically significant. All animal groups receiving piperine $(n=6$ per study group) showed statistically significantly reduced absolute liver weights (approximately $35-39 \%$ reduction compared to the control group) at the end of the piperine administration period. The authors did not comment on those data. These reductions were still existent in the group that had received piperine every day (about $-9 \%$ ) and the group that had received piperine every 4 th day (about $-41 \%$ ) after the recovery period, without reaching statistical significance $(p<0.05)$. Due to the administration of piperine suspended with carboxymethyl cellulose, it is assumed that piperine was given as a bolus once per day. 
In a fourth study with male rats (juvenile animals, 35 days old at baseline; $\mathrm{n}=6$ per group) that involved administration of 0,5 or $10 \mathrm{mg}$ piperine $/ \mathrm{kg}$ bw $/$ day for 30 days by gavage, stimulation of pubertal Leydig cell development (increased Leydig cell number and promoted maturation) and an inhibited spermatogenesis were observed. Regarding the latter effect, the authors only cite histological findings of the testes and epididymides and indicated that already the dose of $5 \mathrm{mg}$ piperine $/ \mathrm{kg} \mathrm{bw} /$ day reduced the epididymal sperm count, but no concrete figures on sperm counts were provided. This lack of data presentation reduces the scientific weight of the evidence provided in this study. Serum testosterone levels were elevated and the FSH levels were lowered in both piperine groups [63,64]. In this regard, the findings in juvenile rats differ from those observed in older rats $[59,62]$.

Overall, the findings from these four studies [16,58-64] largely point in the same direction, with some differences of observed adverse reproductive effects between young adult and juvenile male rats. Concordantly, in young adult male rats, reproductive toxicological effects, i.e., disturbed spermatogenesis (and accompanying effects on testes, epididymides and accessory male reproductive organs of different nature and degrees) were observed with intakes of $10 \mathrm{mg} / \mathrm{kg}$ bw/day [16,58-62]. The less pronounced effects, which were only partly statistically significant, were observed in adult male rats already at $5 \mathrm{mg} / \mathrm{kg}$ bw/day. From these studies, a LOAEL of $5 \mathrm{mg}$ piperine/ $\mathrm{kg}$ bw/day [58,59] and a NOAEL of $1 \mathrm{mg} / \mathrm{kg} \mathrm{bw} /$ day $[60,61]$ can be identified for the endpoint male reproductive toxicity (disturbed spermatogenesis). However, the study of D'Cruz and co-workers used a wide spacing between the tested piperine doses (factor of 10) [60,61]. In one study, adverse paternal reproductive effects observed with repeated daily piperine (bolus) doses of $10 \mathrm{mg} / \mathrm{kg}$ bw were reversible after piperine discontinuation for several weeks [16,62]. Based on information of the four studies on piperine administration, it can be assumed that piperine administration in these studies was carried out via bolus administration. In three of these four studies, piperine administration was via gavage, micropipette or gastric catheter, suggesting bolus administration. The piperine dosage form of the fourth study, i.e., piperine in carboxymethyl cellulose, suggests bolus application as well.

It is noted that these studies are afflicted with certain limitations (statistical analysis of organ weights mainly comprising data on the absolute organ weights and the data on relative organ weights not being available in most cases; small animal group sizes in some studies; in the study of Chen et al., only histological findings were cited but no concrete data on sperm counts were provided; and reduced absolute liver weights not having been reported in other animal studies at this daily dose and contradictory information on the parameters related to testes weights in the study of Chinta and co-workers). However, taken as a whole, the aggregated study findings all point in the same direction and the paternal toxicological reproductive effects, i.e., disturbed spermatogenesis, are corroborated by findings at different levels, such as histopathology, sperm parameters, hormonal changes and changes at the level of enzyme activities, as well as changes in absolute organ weights. The limited scientific significance of absolute organ weights is acknowledged; however, a statistically significant change in the relative testes weights was seen at least in one study [58] with daily doses of $10 \mathrm{mg} / \mathrm{kg}$ bw. The observed differences in hormone levels between the studies of Malini et al. and Chinta et al. on the one hand compared to Chen et al. on the other hand may be related to the different life stages of the investigated male animals (juvenile versus young adult rats) [16,58,59,62-64].

The question of whether the mode of piperine administration in the study by $\mathrm{D}^{\prime} \mathrm{Cruz}$ and co-workers (piperine dissolved in $10 \%$ DMSO, ethanol and groundnut oil) $[60,61]$ or in the study by Chinta and co-workers (together with carboxymethyl cellulose) $[16,62]$ could possibly affect the bioavailability of piperine, leading to increased adverse effects, remains elusive. Adequate data to compare the influence of these modes of administration with the influences of the currently available piperine-containing dietary supplements and the food additives or galenic technics used in their manufacturing on the bioavailability of piperine, are currently not available. 
In contrast to the largely consistent findings from the four studies cited above, different results are available from the 90-day toxicity study with rats used by EFSA (2015) for the evaluation of piperine as a flavouring agent, and which has already been described in (2) in Section 4.2.2 [29,32]. In this study, intakes of $0,5,15$ or $50 \mathrm{mg}$ piperine $/ \mathrm{kg}$ bw/day were administered via feed. In male animals of the 5 and $50 \mathrm{mg} / \mathrm{kg}$ bw-groups, statistically significantly reduced relative epididymis weights (relative to brain weight) were observed. EFSA attributed only limited toxicological relevance to these findings due to the small changes and the non-existent dose dependence, and these changes were without histopathological findings (see also (2) in Section 4.2.2 and Table 1). This study did not include any specific examinations of sperm parameters or LH and FSH blood levels, as these types of investigations are not common in 90-day toxicity studies.

In its assessment, EFSA (2015) did not address the findings of Malini et al. [58,59] and D'Cruz and co-workers [60,61], which were available at that time (since a review of the available scientific literature was not foreseen at this time as part of this assessment procedure).

A major difference between the four animal studies cited first [16,58-64] and the 90day toxicity study used by EFSA seems to be that in the 90-day toxicity study, piperine was administered via feed, resulting in multiple intakes of small quantities spread throughout the day, whereas in the four first-cited animals studies, it can be assumed that piperine was administered as a bolus dose, possibly resulting in higher maximum blood or tissue levels or otherwise increased bioavailability. The bolus administration of piperine in the first four animal studies more closely resembles the usual human use of food supplements, which often bear recommendations relating to 1-3 doses per day.

In this context, it is noted that Daware et al. observed no increased numbers of abnormal sperm cells in a sperm shape abnormality test performed with male mice receiving daily doses of 35-75 $\mathrm{mg}$ piperine/ $\mathrm{kg}$ bw for 5 days [54]. However, this test is primarily performed regarding a genotoxicity assessment.

In in vitro studies, reduced viability and motility of goat sperm cells were seen with high doses of piperine (40-100 $\mu \mathrm{mol} / \mathrm{L})$ added to the sperm culture media [65], as well as impaired fertilization ability of hamster sperms directly exposed to high piperine doses (180-1005 $\mu \mathrm{mol} / \mathrm{L})$ in the capacitation medium [66]. However, the scientific relevance of these in vitro findings remains elusive due to the high piperine concentrations used and the direct exposure of the sperm cells to piperine via culture media, which differs from the exposure of sperm cells resulting from oral piperine intakes.

The mode of action of the bolus doses of piperine on spermatogenesis and the accompanying effects on male reproductive organs remains elusive. With young adult male rats, it has been hypothesized that induced oxidative stress due to depletion of antioxidant enzymes and increased generation of reactive oxygen species (ROS) in epididymis and testis, and activation of the Fas-mediated pathway in testicular germ cells, may contribute to the observed antifertility effects. However, inhibition of the cytochrome P-450 enzymes or other enzymes involved in the synthesis of testicular steroid hormones, interaction of piperine with the active site of the androgen binding protein, induction of hormonal imbalances (effects on serum levels of FSH, LH, sex hormone-binding globulin and testicular testosterone) or other effects on the functional integrity of the testis and the male reproductive organs are also being discussed, and appear possible [16,61,62].

It is noted that even with high bolus doses of fine Piper nigrum fruit powder (25 or $100 \mathrm{mg} / \mathrm{kg}$ bw/day) administered for 20 or 90 days to male mice, negative effects on the sperm count in the cauda epididymis, sperm motility, viability and number of morphologically abnormal spermatozoa were observed (viability not affected with $25 \mathrm{mg} / \mathrm{kg}$ bw dose administered for 20 days), which increased with escalating daily dose and duration of application from 20 to 90 days. After 90 days of pepper powder administration, statistically significantly reduced relative weights (relative to body weight) of the testis, epididymis and seminal vesicle were observed in both dosage groups. No male animal receiving 100 $\mathrm{mg} / \mathrm{kg}$ bw/day for 90 days (other animals were not examined) was fertile in mating trials with untreated female mice $24 \mathrm{~h}$ and 14 days after the termination of pepper administration, 
respectively. The fertility of the treated male animals improved after an 8-week recovery period, but was still (statistically not significantly) reduced at this time point [67]. The fine fruit powder (suspended in water containing milk powder) was administered by a feeding needle; therefore, it can be assumed that the administration occurred as a bolus.

\section{(4) Maternal Reproductive Toxicological and Embryotoxic Effects}

Depending on the time point of piperine administration before or during pregnancy, different reproductive toxicological or embryotoxic effects were observed in female animals.

In the study by Daware et al. (2000), young female mice ( $\mathrm{n}=6$ per group) receiving 0 , 10 or $20 \mathrm{mg}$ piperine/ $\mathrm{kg}$ bw/day for 14 days until the day of mating with untreated male animals displayed a statistically significantly reduced mating rate in the high-dose group (mating performance: $50 \%$ versus $83 \%$ in control group) and in both piperine dose groups a statistically significantly reduced fertility index (fewer mated animals became pregnant; fertility index: $60 \%$ and $66 \%$, respectively). With this piperine administration protocol, the litter size of the pregnant animals and the growth of the pups were not affected. When the piperine doses (10 or $20 \mathrm{mg} / \mathrm{kg}$ bw/day) were administered to female mice from Day 1 through to Day 5 of gestation, significantly reduced implantation rates were observed in both dose groups, with implantations in 1 out of 6 mated animals each in the low- or high-dose group, respectively, versus 6 out of 6 mated animals in the control group. The post-implantation survival was not affected. In this study, piperine was given suspended in a formulation containing $1 \%$ carboyxmethyl cellulose, which was most likely done by bolus administration [54].

Significant implantation-inhibiting effects were also observed in another study by Piyachaturawat et al. (1982) with mice receiving oral bolus doses of $2 \times 12.5$ or $2 \times 50 \mathrm{mg}$ piperine $/ \mathrm{kg}$ bw/day (dissolved in equal volume of DMSO and $95 \%$ ethanol; $\mathrm{n}=19-21$ ) from Day 2 through to Day 5 of gestation, with the implantation rates reduced by $71 \%$ and $90 \%$, respectively, compared to the control group receiving the vehicle only (other oral doses not investigated). In addition, significant abortive effects were observed in mice given the same piperine bolus doses $(2 \times 12.5$ or $2 \times 50 \mathrm{mg} / \mathrm{kg}$ bw $/$ day; $\mathrm{n}=17-21)$ from Day 8 through to Day 12 of gestation (interrupted pregnancies in $58.8 \%$ and $71.4 \%$ of pregnant animals, respectively; other oral doses not investigated). Bolus doses of $25 \mathrm{mg}$ piperine $/ \mathrm{kg}$ bw/day given from gestation Day 15 onwards $(n=8)$ resulted in delayed labour and significantly increased number of dead foetuses ( 6.1 dead foetuses/litter vs. 0.3 dead foetuses/litter in the control group; other oral doses not investigated) [68].

In a study with female rats $(n=6)$, a reduced implantation rate (33\% reduction) was observed with an oral piperine dose of $100 \mathrm{mg}$ piperine $/ \mathrm{kg} \mathrm{bw} /$ day administered from gestation Day 1 through to Day 7 (other doses not investigated) [69].

In female hamsters, which received intra-gastric daily doses of 50 or $100 \mathrm{mg}$ piperine/ $\mathrm{kg}$ bw/day from Day 1 through to Day 4 of the oestrus cycle, followed by hormonally induced superovulation and artificial insemination with spermatozoa of untreated male animals, increased fertilization of eggs in the early phase of fertilization 9 or $24 \mathrm{~h}$ after insemination were observed compared to the control animals [70]. However, due to the applied methodology (hormonally induced superovulation which might interfere with piperine effects on female reproduction, artificial insemination, no information on pregnancy outcome), the scientific significance of these findings remains elusive regarding the effects of piperine on maternal reproduction or embryonic development.

In conclusion, from these studies, a LOAEL of $10 \mathrm{mg} / \mathrm{kg} \mathrm{bw} /$ day can be identified with regard to adverse maternal reproductive and embryotoxic effects in mice [54]. This was the lowest daily dose investigated in these studies.

(5) Interactions with Drugs

Animal studies on the interactions of piperine with drugs are discussed together with the corresponding human studies in Section 4.2.4. 


\subsubsection{Human Studies}

\section{(1) Intervention Studies}

In human single-dose studies, piperine doses of 50 or $500 \mathrm{mg}$ were applied either alone (50 $\mathrm{mg}$ piperine) or in combination (500 mg piperine) with curcumin. However, neither of both studies was designed to address piperine safety issues or provided data on the safety parameters (occurrence/absence of adverse events, haematological or clinical chemistry lab parameters) [45,71].

Human studies with repeated piperine administrations comprise only a small number of studies using piperine without concomitant administration of other substances (drug interaction studies with piperine-only run-in phases of 3-10 days and piperine doses of 15-20 mg/day) [72-79]. In addition, there are a number of other studies in which piperine (in several cases in form of highly piperine-enriched pepper extracts) was given in combination with other substances, e.g., curcumin, resveratrol, Camellia sinensis extract, herbal extracts or others, in order to increase the bioavailability or effectiveness of these substances [80-116]. Some of these piperine combination studies included control groups receiving piperine without concomitant administration of the other substances mentioned above, but these studies lacked control groups receiving no piperine, and were conducted in individuals suffering from different diseases and using various drugs during the course of the study, or no information on product tolerance was provided $[88,89,99,116]$. The combination studies frequently used piperine doses in the range of 4-15 mg/day with study durations of 4-17 weeks, but also other studies are available, in which $60 \mathrm{mg}$ piperine/day administered for 4 days [90], doses of $10 \mathrm{mg} /$ day for 6 months [96,97] or doses of $40 \mathrm{mg} /$ day for 3 or 6 month, respectively [86,111], were used. However, available human studies with piperine administration were primarily conducted to evaluate the efficacy of piperine or the efficacy of the accompanying substances, and in most cases safety issues were only marginally addressed or reported. Most of the studies provided no information or only inadequate information on the occurrence or absence of adverse events and/or no data of the relevant safety lab parameters (a situation that is often found with substances used as ingredients in food supplements [117]). In this regard, it should be noted that the fact that no information on the absence or occurrence of adverse events was provided in several studies cannot be taken as a proof that actually no adverse events occurred [117]. In some of the available studies in which piperine was administered concomitantly with other substances, it is stated that no serious adverse events or severe undesirable effects were reported, leaving open questions regarding the less severe effects. A few studies with combined administration of piperine (4-10 mg/day or unspecified doses) with other substances (iron preparation, resveratrol, curcumin, multi-ingredients or others) reported that no adverse events occurred [82,83,101,106,111-113,118]. Individual studies with combined administration of piperine with other substances (a multi-ingredient product, curcumin) conducted in patients with non-alcoholic fatty liver disease or COPD reported the occurrence of adverse events, comprising gastrointestinal adverse effects (abdominal discomfort or diarrhoea in two studies with $3 / 40$ individuals or 4/45 individuals, respectively; none in placebo groups with $n=40$ or 12 , respectively) or rash (in one study with $1 / 45$ individuals; none in placebo group with $\mathrm{n}=12$ ) [84,103].

None of the identified human studies included investigations regarding the potential effects of piperine on male reproductive capacity (i.e., sperm parameters).

Taken together, due to insufficient data on safety parameters, the lack of investigations into the effects of piperine on human spermatogenesis and/or the combined administration of piperine with other substances conducted in most studies, the available human studies involving piperine administration provide no adequate scientific basis for the assessment of the possible health risks of oral intake of isolated piperine used as single ingredient and ingested in bolus form.

(2) Studies on Reproductive Toxicological Effects 
No published human intervention study could be identified, which included investigations into the effects of bolus intakes of isolated piperine on male reproductive organs, reproductive capacity or sperm parameters. The same applies regarding the reproductive effects in women (pregnant women or women who intend to become pregnant).

In an epidemiological study, a statistically significant inverse association was observed between plasma testosterone concentrations and, among others, plasma piperine levels in healthy middle-aged men (median: 50 years) [119]. However, as already mentioned by the study authors, a statistical association does not imply causality and therefore the scientific significance of these data from this particular study alone regarding male reproductive effects remains elusive (i.e., piperine plasma levels could just be a lifestyle marker).

\subsubsection{Interactions of Piperine with Medicinal Products and Other Substances}

The pharmacokinetic interactions of piperine with various chemically and pharmacologically diverse drugs have been observed in both human and animal studies. In most instances, interactions of piperine with drugs resulted in a better bioavailability of the investigated drugs, exemplified by increases in the maximum plasma/serum concentrations $\left(C_{\max }\right)$ and /or increased AUC values ( $A U C=$ area under the curve) for the respective drugs. These effects are in line with the purported "bio-enhancing" activity of piperine.

In human studies, oral administration of $20 \mathrm{mg}$ piperine/day $(\sim 0,29 \mathrm{mg}$ piperine $/ \mathrm{kg}$ bw based on a body weight of $70 \mathrm{~kg}$ ) for one or several days resulted in improved bioavailability (elevated serum/plasma concentrations and/or elevated AUC values) of the following drugs: propranolol (antihypertensive drug), theophylline (bronchodilatory drug), phenytoin, carbamazepine (antiepileptic drugs), nevirapine (HIV-1 reverse transcriptase inhibitor), chlorzoxazone (muscle relaxant), diclofenac (non-steroidal anti-inflammatory drug) and fexofenadine (antihistaminic drug). In the cases involving administration of $20 \mathrm{mg}$ of piperine/day, the increases in the drug $C_{\max }$ and AUC values were approximately 1.07- to 2.2-fold $\left(C_{\max }\right)$ and 1.09- to 2.7 -fold (AUC values), depending on the drug and drug dosage. Regarding rifampicin (antibiotic drug), such interactions were reported in the context of concomitant administration of $50 \mathrm{mg}$ piperine/day (for details, see Table 2) [72-77,79,120-122].

For midazolam (sedative), prolonged and increased pharmacological effects of the drug (prolonged duration of sedation, increased number of individuals with amnesia) were observed with piperine administration of $15 \mathrm{mg} /$ day for 3 days and subsequent midazolam administration on the 4th day [78].

For the substances $\beta$-carotene and coenzyme $Q_{10}$, increased bioavailability was already observed in the case of combined administration of $5 \mathrm{mg}$ piperine/day with $15 \mathrm{mg} \beta$ carotene/day for 14 days or with $120 \mathrm{mg}$ coenzyme $\mathrm{Q}_{10}$ / day, respectively, for 21 days [123,124]. Regarding curcumin, the $C_{\max }$ or AUC values were approx. 30 or 20 times higher, respectively, when administered together with $20 \mathrm{mg}$ piperine/day [125]. 
Table 2. Effects of piperine on the bioavailability of drugs in human studies.

\begin{tabular}{|c|c|c|c|c|c|}
\hline Drug & Therapeutic Use & $\begin{array}{l}\text { Drug Dose and } \\
\text { Duration }\end{array}$ & $\begin{array}{c}\text { Piperine Dose and } \\
\text { Duration }\end{array}$ & Drug Bioavailability & Reference \\
\hline propranolol & antihypertensive drug & $\begin{array}{l}40 \mathrm{mg} / \text { day as single } \\
\text { dose, preceded by } \\
\text { piperine administration } \\
\text { for } 7 \text { days }\end{array}$ & $20 \mathrm{mg} /$ days for 7 days & $\begin{array}{l}\text { increased bioavailability } \\
\text { (AUC: } 2.03 \text { fold, } C_{\max } \text { : } \\
2.04 \text { fold) }\end{array}$ & \multirow[t]{2}{*}{ Bano et al., 1991 [72] } \\
\hline theophylline & bronchodilatory drug & $\begin{array}{l}150 \mathrm{mg} \text { as single dose, } \\
\text { preceded by piperine } \\
\text { administration for } 7 \\
\text { days }\end{array}$ & $20 \mathrm{mg} /$ days for 7 days & $\begin{array}{l}\text { increased bioavailability } \\
\text { (AUC: } 1.96 \text { fold, } C_{\max } \\
1.62 \text { fold) }\end{array}$ & \\
\hline rifampicine & antibiotic drug & $450 \mathrm{mg}$ as single dose & $50 \mathrm{mg}$ as single dose & $\begin{array}{l}\text { increased bioavailability } \\
\text { (AUC: } 1.71 \text { fold, } C_{\text {max }}: \\
1.25 \text { fold) }\end{array}$ & Zutshi et al., 1985 [122] \\
\hline \multirow[t]{3}{*}{ phenytoin } & \multirow[t]{3}{*}{ antiepileptic drug } & $\begin{array}{l}300 \mathrm{mg} \text { as single dose } \\
\text { preceded by piperine } \\
\text { administration for } 7 \\
\text { days, given to healthy } \\
\text { subjects }\end{array}$ & $20 \mathrm{mg} /$ day for 7 days & $\begin{array}{l}\text { increased bioavailability } \\
\text { (AUC: } 1.50 \text { fold, } C_{\max }: \\
1.27 \text { fold) } C_{\max } \text { increase } \\
\text { was statistically not } \\
\text { significant }\end{array}$ & Bano et al., 1987 [79] \\
\hline & & $\begin{array}{l}150 \mathrm{mg} \text { given to patients } \\
\text { with epilepsy who were } \\
\text { on phenytoin therapy } \\
\text { with } 2 \times 150 \mathrm{mg} / \text { day } \\
\text { for at least } 2 \text { months }\end{array}$ & $20 \mathrm{mg}$ as single dose & $\begin{array}{l}\text { slightly increased } \\
\text { bioavailability } \\
\text { (AUC: } 1.09 \text { fold, } C_{\max } \text { : } \\
1.10 \text { fold) }\end{array}$ & \multirow[t]{2}{*}{$\begin{array}{l}\text { Pattanaik et al., } 2006 \\
\text { [120] }\end{array}$} \\
\hline & & $\begin{array}{l}200 \mathrm{mg} \text { given to patients } \\
\text { with epilepsy who were } \\
\text { on phenytoin therapy } \\
\text { with } 2 \times 200 \mathrm{mg} / \text { days } \\
\text { for at least } 2 \text { months }\end{array}$ & $20 \mathrm{mg}$ as single dose & $\begin{array}{l}\text { slightly increased } \\
\text { bioavailability } \\
\text { (AUC: } 1.17 \text { fold, } C_{\max } \text { : } \\
1.22 \text { fold) }\end{array}$ & \\
\hline \multirow[t]{3}{*}{ carbamazepine } & \multirow[t]{3}{*}{ antiepileptic drug } & $\begin{array}{l}200 \mathrm{mg} \text { as single dose } \\
\text { given to healthy } \\
\text { subjects on day } 11 \\
\text { (applied } 1 \text { day after last } \\
\text { piperine dose) }\end{array}$ & $20 \mathrm{mg} /$ day for 10 days & $\begin{array}{l}\text { increased bioavailability } \\
\text { (AUC } \mathrm{Alast}_{\mathrm{l}}: 1.48 \text { fold, } \\
\mathrm{C}_{\text {max }}: 1.68 \text { fold) }\end{array}$ & Bedada et al., 2017 [73] \\
\hline & & $\begin{array}{l}300 \mathrm{mg} \text { given to patients } \\
\text { with epilepsy who were } \\
\text { on carbamazepine } \\
\text { therapy with } 2 \times 300 \\
\text { mg/day for at least } 2 \\
\text { months }\end{array}$ & $20 \mathrm{mg}$ as single dose & $\begin{array}{l}\text { slightly increased } \\
\text { bioavailability } \\
\text { (AUC: } 1.10 \text { fold, } C_{\max } \text { : } \\
1.07 \text { fold; } C_{\max } \text { increase } \\
\text { was statistically not } \\
\text { significant }\end{array}$ & \multirow[t]{2}{*}{$\begin{array}{l}\text { Pattanaik et al., } 2009 \\
\text { [121] }\end{array}$} \\
\hline & & $\begin{array}{l}500 \mathrm{mg} \text { given to patients } \\
\text { with epilepsy who were } \\
\text { on carbamazepine } \\
\text { therapy with } 2 \times 500 \\
\mathrm{mg} / \text { day for at least } 2 \\
\text { months }\end{array}$ & $20 \mathrm{mg}$ as single dose & $\begin{array}{l}\text { slightly increased } \\
\text { bioavailability } \\
\text { (AUC: } 1.13 \text { fold, } C_{\max } \text { : } \\
1.10 \text { fold) }\end{array}$ & \\
\hline nevirapine & $\begin{array}{l}\text { non-nucleoside HIV-1 } \\
\text { reverse transcriptase } \\
\text { inhibitor }\end{array}$ & $\begin{array}{l}200 \mathrm{mg} \text { as single dose } \\
\text { on day } 7 \text { of piperine } \\
\text { administration }\end{array}$ & $20 \mathrm{mg} /$ day for 7 days & $\begin{array}{l}\text { increased bioavailability } \\
\text { (AUC: } 2.67 \text { fold, } C_{\max } \text { : } \\
2.20 \text { fold) }\end{array}$ & $\begin{array}{l}\text { Kasibhatta and Naidu } \\
2007 \text { [77] }\end{array}$ \\
\hline chlorzoxazone & $\begin{array}{l}\text { centrally acting muscle } \\
\text { relaxant }\end{array}$ & $\begin{array}{l}250 \mathrm{mg} \text { as single dose } \\
\text { on day } 11 \text { (applied } 1 \text { day } \\
\text { after last piperine dose) }\end{array}$ & $20 \mathrm{mg} /$ day for 10 days & $\begin{array}{l}\text { increased bioavailability } \\
\text { (AUC }{ }_{\infty}: 1.69 \text { fold, } C_{\max }: \\
1.58 \text { fold) }\end{array}$ & $\begin{array}{l}\text { Bedada and Boga } 2017 \\
\text { [74] }\end{array}$ \\
\hline fexofenadine & antihistaminic drug & $\begin{array}{l}120 \mathrm{mg} \text { as single dose } \\
\text { on day } 11 \text { (applied } 1 \text { day } \\
\text { after last piperine dose) }\end{array}$ & $20 \mathrm{mg} /$ day for 10 days & $\begin{array}{l}\text { increased bioavailability } \\
\text { (AUC: } 1.68 \text { fold, } \mathrm{C}_{\max } \text { : } \\
1.88 \text { fold) }\end{array}$ & $\begin{array}{l}\text { Bedada and Boga } 2017 \\
\text { [75] }\end{array}$ \\
\hline diclofenac & $\begin{array}{l}\text { nonsteroidal } \\
\text { anti-inflammatory drug }\end{array}$ & $\begin{array}{l}100 \mathrm{mg} \text { as single dose } \\
\text { on day } 11 \text { (applied } 1 \text { day } \\
\text { after last piperine dose) }\end{array}$ & $20 \mathrm{mg} /$ day for 10 days & $\begin{array}{l}\text { increased bioavailability } \\
\text { (AUC: } 1.66 \text { fold, } C_{\max } \text { : } \\
1.64 \text { fold) }\end{array}$ & Bedada et al., 2017 [76] \\
\hline midazolam & sedative & $\begin{array}{l}10 \mathrm{mg} \text { as single dose on } \\
\text { day } 4 \text { (applied } 1 \text { day } \\
\text { after last piperine dose) }\end{array}$ & $15 \mathrm{mg} /$ day for 3 days & $\begin{array}{l}\text { increased clinical effects } \\
\text { - } \quad \text { increased } \\
\text { duration of } \\
\text { sedation } \approx 1.89 \\
\text { fold; } \\
\text { increased } \\
\text { number of } \\
\text { individuals with } \\
\text { drug-induced } \\
\text { amnesia }\end{array}$ & Rezaee et al., 2014 [78] \\
\hline
\end{tabular}

In these human studies referred to above, piperine was administered once daily as a bolus and the piperine and/or drug administration was performed for one or more days according to different administration schedules. The effects of piperine were influenced by the dose of the administered drug and/or the duration of the piperine or the drug administration and/or possibly by the investigated population group, i.e., healthy individuals or individuals suffering from certain diseases (for details, see Table 2 and below). With the exception of the studies on $\beta$-carotene and coenzyme $Q_{10}$, currently no published human 
study could be identified with simultaneous longer-term piperine and drug/substance administration to achieve steady-state levels of piperine and the drug/substance.

In animal studies (rodents or rabbits), higher piperine doses were generally used (2.1-30 mg/kg bw/day), as compared to the doses employed in human studies in which interactions were investigated. The interactions described for the animal studies in most cases also resulted in increased bioavailability (increased serum/plasma $C_{\max }$ and/or increased AUC values) of the investigated drugs. However, interactions in animal studies were observed with several additional drugs, such as ibuprofen, nimesulide, oxyphenylbutazone (non-steroidal anti-inflammatory drugs); amoxycillin, ampicillin, norfloxacin, marbofloxacin, metronidazole (antibiotic drugs); glimepiride, nateglinide (antidiabetic drugs); simvastatin, rosuvastatin (lipid-lowering drugs); verapamil, diltiazeme (calcium channel blockers); sodium valproate (antiepileptic drug); darunavir ethanolate (HIV protease inhibitor); losartan (angiotensin II receptor type 1 antagonist); domperidone (antiemetic drug); almotriptan (anti-migraine drug); and fexofenadine (antihistaminic drug) [126-144].

Increased bioavailability in animal studies has also been observed for a number of other substances (for example for puerarin, resveratrol, emodin, linarin or cannabidiol).

In the case of the drugs nimesulide, oxyphenylbutazone, ibuprofen or nateglinide, the piperine-mediated elevated bioavailability was reported to also be associated with increased drug efficacy. Moreover, increased pharmacological effects, without concomitant measurement of drug levels, have been observed for pentobarbitone (short-acting barbiturate), pentazocine (opioid), sertraline (selective serotonin reuptake inhibitor), midazolam or diazepam [126,134,140,141,145,146].

By contrast, animal studies were also identified in which no improved drug bioavailability or a decreased bioavailability was observed for the combined administration of piperine with drugs, i.e., with cefadroxil, carbamazepine, warfarin or diltiazem [127,147-149].

For diltiazem, a reduced drug bioavailability was observed with administration of 10 or $20 \mathrm{mg}$ of piperine $/ \mathrm{kg} \mathrm{bw} /$ day for 14 days and diltiazem administration on Day 15 (i.e., one day after termination of piperine administration). The repeated dosing of piperine in this study led to induced gene expression of the multidrug transporter P-glycoprotein, which may have played a role in limiting the bioavailability of diltiazem [147].

As a further example, co-administration of warfarin $(2 \mathrm{mg} / \mathrm{kg} \mathrm{bw})$ with piperine $(10 \mathrm{mg} / \mathrm{kg} \mathrm{bw})$ to rats resulted in a decrease in the warfarin $C_{\max }$ and AUC values by 32 and $20 \%$, respectively, combined with a reduced clinical anti-coagulant effect of warfarin [149].

The influence of the study conditions (investigated species, investigated human population, duration of drug treatment and/or schedule of piperine application and piperine dose) on the results of available interaction studies is illustrated by data obtained with carbamazepine. In healthy humans receiving a single dose of carbamazepine (200 mg) on Day 11 after 10 days of piperine administration $(20 \mathrm{mg} /$ day), significant increases in $\mathrm{C}_{\max }(1.7$ fold $)$ and AUC (1.5 fold) values were observed compared to the control group receiving carbamazepine only, which were attributed to piperine-mediated inhibition of the CYP3A4 enzyme [73]. In epilepsy patients, with long-time carbamazepine monotherapy and steady-state carbamazepine plasma levels, small increases in $C_{\max }(1.1$ fold) and AUC (1.1) values were observed after administration of a single dose of $20 \mathrm{mg}$ piperine combined with $500 \mathrm{mg}$ carbamazepine [121]. In an animal study with rats receiving a single combined dose of carbamazepine with 3.5 or $35 \mathrm{mg}$ piperine $/ \mathrm{kg}$ bw, no significant changes in plasma levels $\left(\mathrm{C}_{\max }\right.$ or AUC-values) of carbamazepine and the major carbamazepine metabolite, carbamazepine-10,11-epoxide, were seen compared to the control group receiving carbamazepine only. Rats concomitantly receiving the same carbamazepine and piperine doses for 14 days showed significantly decreased plasma levels of carbamazepine (plasma $C_{\max }$ 25-39\% reduced; plasma AUC 29-37\% reduced). The plasma levels of carbamazepine10,11-epoxide and brain levels of carbamazepine were also reduced in both piperine-treated groups, but reached statistical significance only in the high-dose group. Carbamazepine10,11-epoxide brain levels were also reduced but reached no statistical significance. A decreased plasma concentration of carbamazepine was observed in the high-dose piperine 
group, despite decreased CYP3A2 protein expression in rat liver. The reduced carbamazepine drug and metabolite levels were mainly attributed to a reduced carbamazepine absorption (animals displayed increased defecation and wet faeces with piperine) and a decreased brain penetration of carbamazepine caused by piperine [148].

In addition to the abovementioned study conditions, it can be assumed that the concomitant administration of other bioactive substances together with piperine might also influence the effects of piperine on the bioavailability of the investigated drugs.

Concerning the improved bioavailability seen with several drugs, different underlying mechanisms have been discussed, such as improved drug absorption and/or inhibition of degradation or elimination. In this context, depending on the drug or investigated substance, different mechanisms for influencing absorption and different molecular targets relating to the metabolism of xenobiotics are at the center of discussion, viz. the unspecific gastrointestinal effects (increased splanchnic blood flow), altered membrane dynamics, inhibition of cytochrome P-450 enzymes (CYP3A4, CYP2E1, CYP2C9, etc.), inhibition of multispecific efflux transporters, such as P-glycoprotein, or other mechanisms $[1,15,73-78,120,124,150]$.

It is noted that for the reduced bioavailability of diltiazem observed in an animal study, induction of P-glycoprotein has been considered as an underlying principle [147].

In summary, single or short-term administration of piperine bolus doses combined with several chemically and pharmacologically diverse drugs resulted in interactions, which in most cases led to increased drug bioavailability. However, it can be assumed that such interactions with piperine may also occur with other drugs that have not be tested in this respect so far. Such interactions may vary over time and depend on the used drug, drug dosage and piperine dosage, and may also possibly vary depending on concomitant administration of further bioactive substances. Appropriate investigations in humans are required with the drugs in question to further clarify this issue. Interactions (increased bioavailability of drugs) in humans were observed with several drugs at bolus doses of $20 \mathrm{mg}$ piperine/day. For one drug (midazolam), increased clinical efficacy was reported with bolus administration of $15 \mathrm{mg}$ piperine/day. The findings with $\beta$-carotene and coenzyme $Q_{10}$ indicate that already bolus doses of $5 \mathrm{mg}$ piperine/day may possibly cause interactions with certain substances or drugs.

\section{Discussion}

This review focuses on the evaluation of the safety of isolated piperine used as a single ingredient in food supplements, i.e., in bolus form, in adult individuals. Children and adolescents were not included in the consideration since adult persons constitute the prime target population for food supplements containing piperine.

Piperine is a natural ingredient of Piper nigrum (black pepper) and some other Piper species, e.g., Piper longum. Due to the use of peppercorns as a spice, it is a common component of the human diet. Apart from this source, piperine may be used in isolated form as a flavouring agent in food production.

When pepper is used for food seasoning purposes, piperine is added to food in combination with all other components of the peppercorns (which may influence observed biological effects) and in varying degrees of comminution (which may influence its bioavailability). In this context, it is usually consumed together with large quantities of food and in several portions throughout the day. By contrast, when piperine is used in food supplements, the piperine supply differs greatly in that piperine is ingested in isolated or highly concentrated form and as a bolus (usually in 1-3 portions per day), without any substantial amounts of other pepper components. These differences may influence the bioavailability and biological effects of piperine ingested as a bolus and in isolated form compared to its usual intake via food seasoning.

Currently available human studies with oral piperine administrations provide no adequate scientific basis for the final assessment of the potential health risks associated with intakes of isolated piperine used as a single ingredient and ingested in bolus form. This is a situation also frequently found with other substances used as ingredients of 
dietary supplements. Although hardly any adverse effects (apart from potentially undesirable interactions of piperine with various drugs) were reported in available human studies, it is noted that in most cases safety issues were only marginally addressed or reported. In addition, is to be considered that in many studies piperine was administered in combination with other substances and that the combined administration complicates data interpretation.

However, some currently available human and animal studies already provided indications of potential health risks of bolus doses of isolated piperine.

In human and animal studies with single or short-time application, piperine was shown to interact with various drugs. In most cases, these interactions led to an improved bioavailability of the investigated drugs and are in line with the purported "bio-enhancing" activity of piperine. It can be assumed that such interactions may also occur with other drugs, and can vary, depending on the individual drug, drug dosage, piperine dosage, duration of intake and time span between piperine and drug intake. Additionally, interactions may also possibly vary depending on the concomitant administration of further bioactive substances. For clarification, appropriate investigations in humans are required with the drugs in questions, involving in particular studies with repeated drug and piperine application to reach steady-state levels.

Improved bioavailability can offer advantages in drug therapy if this is performed under medical supervision. Without adequate medical supervision, however, depending on the drug, piperine-based drug interactions may carry the risk of unintended and/or deleteriously increased medicinal drug effects or of the occurrence of adverse drug effects, especially in the case of drugs with a narrow therapeutic range. Increased bioavailability of certain drugs has been observed in several human studies with bolus doses of $20 \mathrm{mg} /$ day (= LOEL), and findings with $\beta$-carotene and coenzyme $\mathrm{Q}_{10}$ suggest that in some cases bolus doses of $5 \mathrm{mg}$ piperine/day might also cause such interactions. Taken together, against the background of these data, it seems advisable that individuals taking medicinal products, especially drugs with known piperine interactions or drugs for which no interaction data are available, should consult a physician prior to the use of isolated piperine as a food supplement.

Based on animal data, further potential health risks or potential risk groups, respectively, of bolus doses of isolated piperine can be identified. In four animal studies with juvenile and young adult rats, largely consistent paternal reproductive toxic effects (see Table 1) were observed at piperine bolus doses of $10 \mathrm{mg} / \mathrm{kg} \mathrm{bw} /$ day [16,58-64].

In young adult rats, male reproductive toxic effects, which were significantly weaker and only partly statistically significant, were observed by Malini et al., already at bolus doses of $5 \mathrm{mg} / \mathrm{kg}$ bw/day [58,59]. On the other hand, a NOAEL of $1 \mathrm{mg}$ piperin $/ \mathrm{kg}$ bw/day (as bolus) can be identified from the study by D'Cruz and co-workers, who used a large spacing between the tested piperine doses (factor 10) [60,61]. Consistently clearer adverse paternal reproductive effects, i.e., disturbed spermatogenesis and accompanying adverse male reproductive effects, however, were observed with doses of $10 \mathrm{mg} / \mathrm{kg} \mathrm{bw} /$ day.

It is to be acknowledged that these studies are afflicted with certain limitations; however, taken as a whole, the aggregated study findings point in the same direction and paternal toxicological reproductive effects, i.e., disturbed spermatogenesis, are corroborated by findings at different levels (i.e., histopathology, sperm parameters, hormonal changes and other parameters).

The reason for the different findings in terms of paternal reproductive toxic effects of these four studies compared to a sub-chronic 90-day animal toxicity study [29] remains elusive. The major difference seems to lie in the method of piperine administration: in the sub-chronic 90-day animal study, piperine was administered via feed, resulting in multiple intakes of small piperine quantities spread throughout the day. In the case of the other four abovementioned animal studies, piperine administration as a bolus can be assumed, possibly resulting in higher peak blood or tissue levels or otherwise increased bioavailability. 
Regarding the reversibility of the disturbed spermatogenesis observed by Chinta and colleagues (see above) [16,62], it remains to be investigated to what extent such reversibility may still be present with piperine administrations lasting longer than 60 days. In addition, it remains to be clarified to what extent these findings may be extrapolated to humans. Even taking into account these findings of Chinta and co-workers with respect to the potential reversibility of the perturbation of spermatogenesis under certain conditions, the consistent paternal reproductive effects observed with bolus doses of $10 \mathrm{mg} / \mathrm{kg}$ bw/day should be classified as being toxicologically relevant and of potential concern.

Human studies that included adequate investigations to clarify the possible effects of bolus doses of isolated piperine on the male reproductive system could not be identified in the course of preparation of the current review. Therefore, as long as this knowledge gap has not been resolved and against the background of the adverse male reproductive effects observed in animal studies with high bolus intakes of isolated piperine, it seems advisable to maintain an adequate margin of exposure between those bolus doses of isolated piperine for which adverse male reproductive effects in animal studies were reported and the daily amounts of isolated piperine used in food supplements.

By using a dose of $10 \mathrm{mg}$ piperine/ $\mathrm{kg}$ bw/day for which adverse male reproductive effects were reported in several animal studies as a point of departure, the application of an uncertainty factor of 3 seems warranted for extrapolation to a NOAEL from this intake level. In addition, for deriving health-based guidance values from animal data, EFSA recommends to use an overall default assessment factor of 100 to account for inter-species and intra-human variability (10 for inter-species variability x 10 for inter-human variability) in the absence of chemical-specific data on the kinetics and/or dynamics [151]. Based on an assumed body weight of $70 \mathrm{~kg}$, this approach would lead to a health-based guidance value of $2.3 \mathrm{mg} /$ day $(10 \mathrm{mg} / \mathrm{kg} \mathrm{bw} /$ day $\times 70 \mathrm{~kg} \mathrm{bw} /(3 \times 100))$ for piperine when used in isolated form via bolus administration, i.e., as a food supplement. This intake seems to be low compared to estimates of daily piperine intakes resulting from the usual culinary use of pepper in normal human diet. However, it should be taken into account that the intake of piperine in isolated form may not be directly comparable to its intake in conjunction with all other pepper ingredients and various degrees of comminution of the peppercorn. On the other hand, the effect of pepper consumption (in particular of high bolus doses with a high degree of comminution) on human male reproductive capacity remains to be clarified.

The health-based guidance value of $2.3 \mathrm{mg} /$ day, as calculated above, which would currently be expected to provide an adequate level of protection with respect to potential male reproductive toxicity, would also be below the piperine bolus doses for which interactions with concomitantly administered drugs/substances have been observed.

In animal studies, maternal reproductive toxicity and embryotoxic effects were observed with piperine bolus doses of 10-25 mg/ kg bw/day, which varied, depending on the time of piperine administration with regard to the day of mating, the duration of time covered during gestation and the piperine dose $(10 \mathrm{mg} / \mathrm{kg}$ bw/day: reduced fertility index, reduced implantation rates; $25 \mathrm{mg} \mathrm{kg} \mathrm{bw/day:} \mathrm{reduced} \mathrm{implantation} \mathrm{rates,} \mathrm{abortive}$ effects, delayed labour and increased foetal mortality) [54,68]. It should be noted that the observed adverse effects occurred in these studies at the lowest piperine bolus doses tested and that certain adverse effects were only investigated at $25 \mathrm{mg} / \mathrm{kg}$ bw / day. From the available animal studies, a LOAEL of $10 \mathrm{mg} / \mathrm{kg}$ bw/day, but no NOAEL regarding maternal reproductive toxicity and embryotoxic effects could be identified. It remains to be clarified whether the use of DMSO in the oral piperine application by Piyachaturawat et al. (1982) might have had an influence on the bioavailability or observed effects of piperine. However, adverse maternal reproductive and embryotoxic effects were also observed in a second study [54].

With regard to the potential health risks for which there are indications when using isolated piperine in bolus doses (drug interactions, disturbed spermatogenesis, adverse maternal reproductive and embryotoxic effects), it remains to be clarified whether these risks may be influenced by other bio-active, additional ingredients in food supplements 
ingested together with piperine. In principal, the same considerations apply to highly piperine-enriched pepper extracts, although the difference between some highly piperineenriched extracts and the piperine preparations supplied from chemical companies (purity: $\geq 97 \%$ ), used for instance in the cited studies of Chinta et al. [16,62] or D'Cruz et al. [60,61], does not seem to be substantial. However, in cases involving either other bio-active ingredients and/or highly piperine-enriched pepper extracts, any claimed mitigation or elimination of the adverse effects described above should be supported by adequate scientific investigations and data.

In conclusion, human and animal studies with single or short-term application of isolated piperine used in bolus form revealed interactions of the substance with several drugs, which can give rise to potential health risks, and based on which individuals taking medications can be identified as a potential risk group. For individuals taking medicinal products (especially drugs with known piperine interactions or drugs for which no interaction data are available), it seems advisable to consult a physician prior to the use of isolated piperine as a food supplement.

Animal studies with higher daily piperine bolus doses provide indications for further potential health risks (disturbed spermatogenesis; adverse maternal reproductive and embryotoxic effects), for which no adequate human data are currently available.

Considering that a distinct NOAEL for maternal reproductive and embryotoxic effects could currently not be identified from the available animal studies, it seems advisable for pregnant women to abstain from the use of food supplements containing isolated piperine. Moreover, the reduced implantation rates that were reported in animal studies may also be of relevance for women who wish to become pregnant.

Regarding the observed adverse paternal reproduction effects in animal studies and the lack of information on the effects of bolus doses of isolated piperine on the human male reproductive system, it appears prudent to maintain an adequate margin of exposure between those bolus doses that produced adverse paternal reproductive effects in animal studies and the maximum daily amounts of isolated piperine in food supplements.

Considering the uncertainties outlined above, the importance of addressing the existing knowledge gaps regarding effects of bolus doses of isolated piperine on human male reproductive capacity in future human intervention studies, by including specific investigations into this endpoint in the study design, is emphasised.

Author Contributions: Conceptualization, R.Z.; writing—original draft preparation, R.Z.; writingreview \& editing, R.Z., K.H., A.L. and K.I.H.-E. All authors have read and agreed the published version of the manuscript.

Funding: This research received no external funding.

Institutional Review Board Statement: Not applicable.

Informed Consent Statement: Not applicable.

Data Availability Statement: Not applicable.

Acknowledgments: The authors would like to thank the Dietary Exposure and Aggregated Exposure Unit of the German Federal Institute for Risk Assessment's (BfR), in particular Christine Sommerfeld, for conducting the estimation of the daily pepper intake of the German population (14-80 years) and Britta Nagl and Carolin Schopf for technical assistance in the preparation of the manuscript.

Conflicts of Interest: The authors declare no conflict of interest. 


$\begin{array}{ll}\text { Abbreviations } \\ \text { AUC } & \begin{array}{l}\text { area under the curve } \\ \text { bw }\end{array} \\ \text { body weight } \\ \text { Cmax }_{\text {CMEC }} & \text { maximum (or peak) serum/plasma concentration of a drug/substance } \\ \text { (Australian) Complementary Medicines Evaluation Committee } \\ \text { COPD } & \text { chronic obstructive pulmonary disease } \\ \text { DMSO } & \text { dimethyl sulfoxide } \\ \text { EFSA } & \text { European Food Safety Authority } \\ \text { FAO } & \text { Food and Agriculture Organization } \\ \text { FSH } & \text { follicle-stimulating hormone } \\ \text { i.g. } & \text { intragastric } \\ \text { i.v. } & \text { intravenous } \\ \text { JECFA } & \text { Joint FAO/WHO Expert Committee on Food Additives } \\ \text { LH } & \text { luteinizing hormone } \\ \text { LOAEL } & \text { Lowest observed adverse effect level } \\ \text { LOEL } & \text { Lowest observed effect level } \\ \text { MOE } & \text { Margin of Exposure } \\ \text { MSDI } & \text { Maximised Survey-derived Daily Intake } \\ \text { NOAEL } & \text { No observed adverse effect level } \\ \text { NOEL } & \text { No observed effect level } \\ \text { OECD } & \text { Organization for Economic Co-operation and Development } \\ \text { mTAMDIs } & \text { Modified Theoretical Added Maximum Daily Intakes } \\ \text { TGA } & \text { (Australien) Therapuetic Goods Administration } \\ \text { Tmax } & \text { time to reach maximum serum/plasma concentration after administration of a drug/substanc } \\ \text { WHO } & \text { World Health Organization } \\ & \end{array}$

\section{References}

1. Lee, S.H.; Kim, H.Y.; Back, S.Y.; Han, H.K. Piperine-mediated drug interactions and formulation strategy for piperine: Recent advances and future perspectives. Expert Opin. Drug Metab. Toxicol. 2018, 14, 43-57. [CrossRef]

2. VKM. Norwegian Scientific Committee for Food Safety. Risk assessment of "other substances"-Piperine. Opinion of the Panel Food Additives, Flavourings, Processing Aids, Materials in Contact with Food and Cosmetics of the Norwegian Scientific Committee for Food Safety. VKM Rep. 2016, 31, 1-43. Available online: https://vkm.no/download/18.645b840415d03a2fe8f25ff2 /1502802968337/08fcbfacc1.pdf (accessed on 2 June 2021).

3. EFSA. European Food Safety Authority. Compendium of botanicals reported to contain naturally occuring substances of possible concern for human health when used in food and food supplements. EFSA J. 2012, 10, 2663. [CrossRef]

4. ECHA. European Chemicals Agency. Piperine. Substance Infocard. Available online: https://echa.europa.eu/de/substanceinformation/- / substanceinfo/100.002.135 (accessed on 2 June 2021).

5. ChemIDplus. Substance name: Piperine [USP]. In National Institutes of Health/U.S. National Library of Medicine. Available online: https:/ / chem.nlm.nih.gov/chemidplus/name/piperine \%20\%5Busp \%5D (accessed on 2 June 2021).

6. Stohr, J.R.; Xiao, P.G.; Bauer, R. Constituents of Chinese Piper species and their inhibitory activity on prostaglandin and leukotriene biosynthesis in vitro. J. Ethnopharmacol. 2001, 75, 133-139. [CrossRef]

7. Haq, I.U.; Imran, M.; Nadeem, M.; Tufail, T.; Gondal, T.A.; Mubarak, M.S. Piperine: A review of its biological effects. Phytother. Res. PTR 2021, 35, 680-700. [CrossRef] [PubMed]

8. Vasavirama, K.; Upender, M. Piperine: A valuable alkaloid from piper species. Int. J. Pharm. Pharm. Sci. 2014, 6, 34-38.

9. Orav, A.; Stulova, I.; Kailas, T.; Muurisepp, M. Effect of storage on the essential oil composition of Piper nigrum L. fruits of different ripening states. J. Agric. Food Chem. 2004, 52, 2582-2586. [CrossRef]

10. Kozukue, N.; Park, M.S.; Choi, S.H.; Lee, S.U.; Ohnishi-Kameyama, M.; Levin, C.E.; Friedman, M. Kinetics of light-induced cis-trans isomerization of four piperines and their levels in ground black peppers as determined by HPLC and LC/MS. J. Agric. Food Chem. 2007, 55, 7131-7139. [CrossRef]

11. Chinta, G.; Syed, S.B.; Coumar, M.S.; Periyasamy, L. Piperine: A comprehensive review of pre-clinical and clinical investigations. Curr. Bioact. Compd. 2015, 11, 156-169. [CrossRef]

12. Chavarria, D.; Silva, T.; Magalhaes e Silva, D.; Remiao, F.; Borges, F. Lessons from black pepper: Piperine and derivatives thereof. Expert Opin. Ther. Pat. 2016, 26, 245-264. [CrossRef] [PubMed]

13. Gorgani, L.; Mohammadi, M.; Najafpour, G.D.; Nikzad, M. Piperine-the bioactive compound of black pepper: From isolation to medicinal formulations. Compr. Rev. Food Sci. Food Saf. 2017, 16, 124-140. [CrossRef]

14. Singh, A.; Duggal, S. Piperine-Review of advances in pharmacology. Int. J. Pharm. Sci. Nanotechnol. 2009, 2, 615-620. [CrossRef]

15. Srinivasan, K. Black pepper and its pungent principle-piperine: A review of diverse physiological effects. Crit. Rev. Food Sci. Nutr. 2007, 47, 735-748. [CrossRef] 
16. Chinta, G.; Periyasamy, L. Reversible anti-spermatogenic effect of piperine on epididymis and seminal vesicles of albino rats. Drug Res. 2016, 66, 420-426. [CrossRef]

17. Vijayakumar, R.S.; Surya, D.; Nalini, N. Antioxidant efficacy of black pepper (Piper nigrum L.) and piperine in rats with high fat diet induced oxidative stress. Redox Rep. Commun. Free. Radic. Res. 2004, 9, 105-110. [CrossRef]

18. Bakshi, H.; Nagpal, M.; Singh, M.; Dhingra, G.A.; Aggarwal, G. Propitious profile of peppery piperine. Curr. Mol. Pharmacol. 2020. E-pub ahead of print. [CrossRef]

19. Raza, K.; Kumar, D.; Kiran, C.; Kumar, M.; Guru, S.K.; Kumar, P.; Arora, S.; Sharma, G.; Bhushan, S.; Katare, O.P. Conjugation of Docetaxel with multiwalled carbon nanotubes and codelivery with piperine: Implications on pharmacokinetic profile and anticancer activity. Mol. Pharm. 2016, 13, 2423-2432. [CrossRef]

20. Cherniakov, I.; Izgelov, D.; Barasch, D.; Davidson, E.; Domb, A.J.; Hoffman, A. Piperine-pro-nanolipospheres as a novel oral delivery system of cannabinoids: Pharmacokinetic evaluation in healthy volunteers in comparison to buccal spray administration. J. Control. Release 2017, 266, 1-7. [CrossRef]

21. Zachariah, T.J.; Parthasarathy, V.A. Black pepper. In Chemistry of Spices; Parthasarathy, V.A., Chempakam, B., Zachariah, T.J., Eds.; CAB International: Wallingford, UK, 2008; pp. 21-40.

22. Liu, H.L.; Luo, R.; Chen, X.Q.; Ba, Y.Y.; Zheng, L.; Guo, W.W.; Wu, X. Identification and simultaneous quantification of five alkaloids in Piper longum L. by HPLC-ESI-MS(n) and UFLC-ESI-MS/MS and their application to Piper nigrum L. Food Chem. 2015, 177, 191-196. [CrossRef]

23. Bao, N.; Ochir, S.; Sun, Z.; Borjihan, G.; Yamagishi, T. Occurrence of piperidine alkaloids in Piper species collected in different areas. J. Nat. Med. 2014, 68, 211-214. [CrossRef]

24. Zaveri, M.; Khandhar, A.; Patel, S.; Patel, A. Chemistry and pharmacology of Piper longum L. Int. J. Pharm. Sci. Rev. Res. 2010, 5, 67-76.

25. Liu, H.; Zheng, J.; Liu, P.; Zeng, F. Pulverizing processes affect the chemical quality and thermal property of black, white, and green pepper (Piper nigrum L.). J. Food Sci. Technol. 2018, 55, 2130-2142. [CrossRef]

26. Nisha, P.; Singhal, R.S.; Pandit, A.B. The degradation kinetics of flavor in black pepper (Piper nigrum L.). J. Food Eng. 2009, 92, 44-49. [CrossRef]

27. Suresh, D.; Manjunatha, H.; Srinivasan, K. Effect of heat processing of spices on the concentrations of their bioactive principles: Turmeric (Curcuma longa), red pepper (Capsicum annuum) and black pepper (Piper nigrum). J. Food Compost. Anal. 2007, 20, 346-351. [CrossRef]

28. Therapeutic Goods Administration. CMEC 64 Complementary Medicines Evaluation Committee, Extracted Ratified Minutes. Sixty-Fourth Meeting, 14 December 2007. Available online: https://www.tga.gov.au/sites/default/files/cmec-minutes-64.pdf (accessed on 2 June 2021).

29. Bastaki, M.; Aubanel, M.; Bauter, M.; Cachet, T.; Demyttenaere, J.; Diop, M.M.; Harman, C.L.; Hayashi, S.M.; Krammer, G.; $\mathrm{Li}, \mathrm{X}$; ; et al. Absence of adverse effects following administration of piperine in the diet of Sprague-Dawley rats for 90 days. Food Chem. Toxicol. 2018, 120, 213-221. [CrossRef]

30. MRI. Nationale Verzehrsstudie II; Ergebnisbericht, Teil 2; Max Rubner-Institut: Karlsruhe, Germany, 2008.

31. Ferrucci, L.M.; Daniel, C.R.; Kapur, K.; Chadha, P.; Shetty, H.; Graubard, B.I.; George, P.S.; Osborne, W.; Yurgalevitch, S.; Devasenapathy, N.; et al. Measurement of spices and seasonings in India: Opportunities for cancer epidemiology and prevention. Asian Pac. J. Cancer Prev. APJCP 2010, 11, 1621-1629. [PubMed]

32. EFSA. European Food Safety Authority. Scientific Opinion on Flavouring Group Evaluation 86, Revision 2 (FGE.86Rev2): Consideration of aliphatic and arylalkyl amines and amides evaluated by JECFA (65th meeting). EFSA J. 2015, 13, 3998. [CrossRef]

33. Joint FAO/WHO Expert Committee on Food Additives. Compendium of food additive specifications Addendum 13. In Proceedings of the Joint FAO/WHO Expert Committee on Food Additives (JECFA) 65th Meeting, Geneva, Switzerland, 7-15 June 2005.

34. Bhat, B.G.; Chandrasekhara, N. Studies on the metabolism of piperine: Absorption, tissue distribution and excretion of urinary conjugates in rats. Toxicology 1986, 40, 83-92. [CrossRef]

35. Bhat, B.G.; Chandrasekhara, N. Metabolic disposition of piperine in the rat. Toxicology 1987, 44, 99-106. [CrossRef]

36. Suresh, D.; Srinivasan, K. Tissue distribution \& elimination of capsaicin, piperine \& curcumin following oral intake in rats. Indian J. Med. Res. 2010, 131, 682-691. [PubMed]

37. Li, C.; Wang, Q.; Ren, T.; Zhang, Y.; Lam, C.W.K.; Chow, M.S.S.; Zuo, Z. Non-linear pharmacokinetics of piperine and its herb-drug interactions with docetaxel in Sprague-Dawley rats. J. Pharm. Biomed. Anal. 2016, 128, 286-293. [CrossRef]

38. Gao, T.; Xue, H.; Lu, L.; Zhang, T.; Han, H. Characterization of piperine metabolites in rats by ultra-high-performance liquid chromatography with electrospray ionization quadruple time-of-flight tandem mass spectrometry. Rapid Commun. Mass Spectrom. RCM 2017, 31, 901-910. [CrossRef] [PubMed]

39. Shang, Z.; Cai, W.; Cao, Y.; Wang, F.; Wang, Z.; Lu, J.; Zhang, J. An integrated strategy for rapid discovery and identification of the sequential piperine metabolites in rats using ultra high-performance liquid chromatography/high resolution mass spectrometery. J. Pharm. Biomed. Anal. 2017, 146, 387-401. [CrossRef]

40. Ternes, W.; Krause, E.L. Characterization and determination of piperine and piperine isomers in eggs. Anal. Bioanal. Chem. 2002, 374, 155-160. [CrossRef] [PubMed] 
41. Sahu, P.K.; Sharma, A.; Rayees, S.; Kour, G.; Singh, A.; Khullar, M.; Magotra, A.; Paswan, S.K.; Gupta, M.; Ahmed, I.; et al. Pharmacokinetic study of piperine in wistar rats after oral and intravenous administration. Int. J. Drug Deliv. $2014,6,82-87$.

42. Ren, T.; Wang, Q.; Li, C.; Yang, M.; Zuo, Z. Efficient brain uptake of piperine and its pharmacokinetics characterization after oral administration. Xenobiotica 2018, 48, 1249-1257. [CrossRef]

43. Shao, B.; Cui, C.; Ji, H.; Tang, J.; Wang, Z.; Liu, H.; Qin, M.; Li, X.; Wu, L. Enhanced oral bioavailability of piperine by selfemulsifying drug delivery systems: In vitro, in vivo and in situ intestinal permeability studies. Drug Deliv. 2015, $22,740-747$. [CrossRef]

44. Bajad, S.; Singla, A.K.; Bedi, K.L. Liquid chromatographic method for determination of piperine in rat plasma: Application to pharmacokinetics. J. Chromatogr. B Anal. Technol. Biomed. Life Sci. 2002, 776, 245-249. [CrossRef]

45. Kakarala, M.; Dubey, S.K.; Tarnowski, M.; Cheng, C.; Liyanage, S.; Strawder, T.; Tazi, K.; Sen, A.; Djuric, Z.; Brenner, D.E. Ultra-low flow liquid chromatography assay with ultraviolet (UV) detection for piperine quantitation in human plasma. J. Agric. Food Chem. 2010, 58, 6594-6599. [CrossRef]

46. Hölzel, C.; Spiteller, G. Piperin—ein Beispiel für individuell unterschiedliche (polymorphe) Metabolisierung einer allgegenwärtigen Nahrungskomponente. Liebigs Ann. Chem. 1984, 1984, 1319-1331. [CrossRef]

47. Li, Y.; Li, M.; Wang, Z.; Wen, M.; Tang, J. Identification of the metabolites of piperine via hepatocyte incubation and liquid chromatography combined with diode-array detection and high-resolution mass spectrometry. Rapid Commun. Mass Spectrom. RCM 2020, 34, e8947. [CrossRef]

48. EFSA. European Food Safety Authority. Flavouring Group Evaluation 86, (FGE.86)—Consideration of aliphatic and aromatic amines and amides evaluated by JECFA (65th meeting)—Scientific Opinion of the Panel on Food Additives-Flavourings, Processing Aids and Materials in Contact with Food. EFSA J. 2008, 745, 1-46. [CrossRef]

49. EFSA. European Food Safety Authority. Scientific Opinion on Flavouring Group Evaluation 86, Revision 1 (FGE.86Rev1): Consideration of aliphatic and aromatic amines and amides evaluated by JECFA (65th meeting). EFSA J. 2011, 9, 1926. [CrossRef]

50. JECFA. Joint FAO/WHO Expert Committee on Food Additives. Safety evaluation of certain food additives. WHO Food Addit. Ser. 2006, 56, 327-403.

51. Health Canada. Monograph black pepper-Piper nigrum (25 March 2019). Available online: http://webprod.hc-sc.gc.ca/nhpidbdipsn/atReq.do?atid=blackpepper.poivrenoir\&lang=eng (accessed on 2 June 2021).

52. Muralidhara; Narasimhamurthy, K. Lack of genotoxic effects of piperine, (the active principle of black pepper) in albino mice. J. Food Saf. 1990, 11, 39-48. [CrossRef]

53. Karekar, V.R.; Mujumdar, A.M.; Joshi, S.S.; Dhuley, J.; Shinde, S.L.; Ghaskadbi, S. Assessment of genotoxic effect of piperine using Salmonella typhimurium and somatic and somatic and germ cells of Swiss albino mice. Arzneimittel-Forschung 1996, 46, 972-975.

54. Daware, M.B.; Mujumdar, A.M.; Ghaskadbi, S. Reproductive toxicity of piperine in Swiss albino mice. Planta Med. 2000, 66, 231-236. [CrossRef]

55. Thiel, A.; Buskens, C.; Woehrle, T.; Etheve, S.; Schoenmakers, A.; Fehr, M.; Beilstein, P. Black pepper constituent piperine: Genotoxicity studies in vitro and in vivo. Food Chem. Toxicol. 2014, 66, 350-357. [CrossRef]

56. Piyachaturawat, P.; Glinsukon, T.; Toskulkao, C. Acute and subacute toxicity of piperine in mice, rats and hamsters. Toxicol. Lett. 1983, 16, 351-359. [CrossRef]

57. Bhat, B.G.; Chandrasekhara, N. Lack of adverse influence of black pepper, its oleoresin and piperine in the weanling rat. J. Food Saf. 1986, 7, 215-223. [CrossRef]

58. Malini, T.; Arunakaran, J.; Aruldhas, M.M.; Govindarajulu, P. Effects of piperine on the lipid composition and enzymes of the pyruvate-malate cycle in the testis of the rat in vivo. Biochem. Mol. Biol. Int. 1999, 47, 537-545. [CrossRef]

59. Malini, T.; Manimaran, R.R.; Arunakaran, J.; Aruldhas, M.M.; Govindarajulu, P. Effects of piperine on testis of albino rats. J. Ethnopharmacol. 1999, 64, 219-225. [CrossRef]

60. D'Cruz, S.C.; Mathur, P.P. Effect of piperine on the epididymis of adult male rats. Asian J. Androl. 2005, 7, 363-368. [CrossRef]

61. D'Cruz, S.C.; Vaithinathan, S.; Saradha, B.; Mathur, P.P. Piperine activates testicular apoptosis in adult rats. J. Biochem. Mol. Toxicol. 2008, 22, 382-388. [CrossRef]

62. Chinta, G.; Coumar, M.S.; Periyasamy, L. Reversible testicular toxicity of piperine on male albino rats. Pharmacogn. Mag. 2017, 13, S525-S532. [CrossRef]

63. Chen, X.; Ge, F.; Lian, Q.; Ge, F. Piperine promotes pubertal leydig cell development but inhibits spermatogenesis in rats. Andrology 2018, 6, 60. [CrossRef]

64. Chen, X.; Ge, F.; Liu, J.; Bao, S.; Chen, Y.; Li, D.; Li, Y.; Huang, T.; Chen, X.; Zhu, Q.; et al. Diverged effects of piperine on testicular development: Stimulating leydig cell development but inhibiting spermatogenesis in rats. Front. Pharmacol. 2018, 9, 244. [CrossRef]

65. Janarthanan, R.; Chinta, G.; Jesthadi, D.; Shanmuganathan, B.; Periyasamy, L. Effect of piperine on goat epididymal spermatozoa: An in vitro study. Asian J. Pharm. Clin. Res. 2014, 7, 57-61.

66. Piyachaturawat, P.; Sriwattana, W.; Damrongphol, P.; Pholpramool, C. Effects of piperine on hamster sperm capacitation and fertilization in vitro. Int. J. Androl. 1991, 14, 283-290. [CrossRef]

67. Mishra, R.K.; Singh, S.K. Antispermatogenic and antifertility effects of fruits of Piper nigrum L. in mice. Indian J. Exp. Biol. 2009, 47, 706-714. [PubMed] 
68. Piyachaturawat, P.; Glinsukon, T.; Peugvicha, P. Postcoital antifertility effect of piperine. Contraception 1982, 26, 625-633. [CrossRef]

69. Chandhoke, N.; Gupta, S.; Dhar, S. Interceptive activity of various species of Piper, their natural amides and semi-synthetic analogs. Indian J. Pharm. Sci. 1978, 40, 113-116.

70. Piyachaturawat, P.; Pholpramool, C. Enhancement of fertilization by piperine in hamsters. Cell Biol. Int. 1997, 21, 405-409. [CrossRef]

71. Sethi, P.; Dua, V.K.; Mohanty, S.; Mishra, S.K.; Jain, R.; Edwards, G. Development and validation of a reversed phase hplc method for simultaneous determination of curcumin and piperine in human plasma for application in clinical pharmacological studies. $J$. Liq. Chromatogr. Relat. Technol. 2009, 32, 2961-2974. [CrossRef]

72. Bano, G.; Raina, R.K.; Zutshi, U.; Bedi, K.L.; Johri, R.K.; Sharma, S.C. Effect of piperine on bioavailability and pharmacokinetics of propranolol and theophylline in healthy volunteers. Eur. J. Clin. Pharmacol. 1991, 41, 615-617. [CrossRef]

73. Bedada, S.K.; Appani, R.; Boga, P.K. Effect of piperine on the metabolism and pharmacokinetics of carbamazepine in healthy volunteers. Drug Res. 2017, 67, 46-51. [CrossRef]

74. Bedada, S.K.; Boga, P.K. Effect of piperine on CYP2E1 enzyme activity of chlorzoxazone in healthy volunteers. Xenobiotica 2017, 47, 1035-1041. [CrossRef] [PubMed]

75. Bedada, S.K.; Boga, P.K. The influence of piperine on the pharmacokinetics of fexofenadine, a P-glycoprotein substrate, in healthy volunteers. Eur. J. Clin. Pharmacol. 2017, 73, 343-349. [CrossRef]

76. Bedada, S.K.; Boga, P.K.; Kotakonda, H.K. Study on influence of piperine treatment on the pharmacokinetics of diclofenac in healthy volunteers. Xenobiotica 2017, 47, 127-132. [CrossRef]

77. Kasibhatta, R.; Naidu, M.U. Influence of piperine on the pharmacokinetics of nevirapine under fasting conditions: A randomised, crossover, placebo-controlled study. Drugs RED 2007, 8, 383-391. [CrossRef]

78. Rezaee, M.M.; Kazemi, S.; Kazemi, M.T.; Gharooee, S.; Yazdani, E.; Gharooee, H.; Shiran, M.R.; Moghadamnia, A.A. The effect of piperine on midazolam plasma concentration in healthy volunteers, a research on the CYP3A-involving metabolism. DARU J. Pharm. Sci. 2014, 22, 8. [CrossRef] [PubMed]

79. Bano, G.; Amla, V.; Raina, R.K.; Zutshi, U.; Chopra, C.L. The effect of piperine on pharmacokinetics of phenytoin in healthy volunteers. Planta Med. 1987, 53, 568-569. [CrossRef]

80. Rondanelli, M.; Opizzi, A.; Perna, S.; Faliva, M.; Solerte, S.B.; Fioravanti, M.; Klersy, C.; Cava, E.; Paolini, M.; Scavone, L.; et al. Improvement in insulin resistance and favourable changes in plasma inflammatory adipokines after weight loss associated with two months' consumption of a combination of bioactive food ingredients in overweight subjects. Endocrine 2013, 44, 391-401. [CrossRef] [PubMed]

81. Rondanelli, M.; Opizzi, A.; Perna, S.; Faliva, M.; Solerte, S.B.; Fioravanti, M.; Klersy, C.; Edda, C.; Maddalena, P.; Luciano, S.; et al. Acute effect on satiety, resting energy expenditure, respiratory quotient, glucagon-like peptide-1, free fatty acids, and glycerol following consumption of a combination of bioactive food ingredients in overweight subjects. J. Am. Coll. Nutr. 2013, 32, 41-49. [CrossRef]

82. Peterson, C.T.; Vaughn, A.R.; Sharma, V.; Chopra, D.; Mills, P.J.; Peterson, S.N.; Sivamani, R.K. Effects of turmeric and curcumin dietary supplementation on human gut microbiota: A double-blind, randomized, placebo-controlled pilot study. J. Evid.-Based Integr. Med. 2018, 23, 1-8. [CrossRef]

83. Polley, K.R.; Jenkins, N.; O'Connor, P.; McCully, K. Influence of exercise training with resveratrol supplementation on skeletal muscle mitochondrial capacity. Appl. Physiol. Nutr. Metab. 2016, 41, 26-32. [CrossRef]

84. Cicero, A.F.G.; Sahebkar, A.; Fogacci, F.; Bove, M.; Giovannini, M.; Borghi, C. Effects of phytosomal curcumin on anthropometric parameters, insulin resistance, cortisolemia and non-alcoholic fatty liver disease indices: A double-blind, placebo-controlled clinical trial. Eur. J. Nutr. 2020, 59, 477-483. [CrossRef] [PubMed]

85. Di Pierro, F.; Settembre, R. Safety and efficacy of an add-on therapy with curcumin phytosome and piperine and/or lipoic acid in subjects with a diagnosis of peripheral neuropathy treated with dexibuprofen. J. Pain Res. 2013, 6, 497-503. [CrossRef]

86. Haghpanah, S.; Zarei, T.; Eshghi, P.; Zekavat, O.; Bordbar, M.; Hoormand, M.; Karimi, M. Efficacy and safety of resveratrol, an oral hemoglobin F-augmenting agent, in patients with beta-thalassemia intermedia. Ann. Hematol. 2018, 97, 1919-1924. [CrossRef]

87. Panahi, Y.; Hosseini, M.S.; Khalili, N.; Naimi, E.; Majeed, M.; Sahebkar, A. Antioxidant and anti-inflammatory effects of curcuminoid-piperine combination in subjects with metabolic syndrome: A randomized controlled trial and an updated metaanalysis. Clin. Nutr. 2015, 34, 1101-1108. [CrossRef]

88. Panahi, Y.; Khalili, N.; Hosseini, M.S.; Abbasinazari, M.; Sahebkar, A. Lipid-modifying effects of adjunctive therapy with curcuminoids-piperine combination in patients with metabolic syndrome: Results of a randomized controlled trial. Complementary Ther. Med. 2014, 22, 851-857. [CrossRef]

89. Panahi, Y.; Khalili, N.; Sahebi, E.; Namazi, S.; Simental-Mendia, L.E.; Majeed, M.; Sahebkar, A. Effects of curcuminoids plus piperine on glycemic, hepatic and inflammatory biomarkers in patients with type 2 diabetes mellitus: A randomized double-blind placebo-controlled trial. Drug Res. 2018, 68, 403-409. [CrossRef]

90. Delecroix, B.; Abaidia, A.E.; Leduc, C.; Dawson, B.; Dupont, G. Curcumin and piperine supplementation and recovery following exercise induced muscle damage: A randomized controlled trial. J. Sports Sci. Med. 2017, 16, 147-153. [PubMed]

91. Gilardini, L.; Pasqualinotto, L.; Di Pierro, F.; Risso, P.; Invitti, C. Effects of Greenselect Phytosome(R) on weight maintenance after weight loss in obese women: A randomized placebo-controlled study. BMC Complementary Altern. Med. 2016, 16, 233. [CrossRef] 
92. Panahi, Y.; Khalili, N.; Sahebi, E.; Namazi, S.; Atkin, S.L.; Majeed, M.; Sahebkar, A. Curcuminoids plus piperine modulate adipokines in type 2 diabetes mellitus. Curr. Clin. Pharmacol. 2017, 12, 253-258. [CrossRef] [PubMed]

93. Panahi, Y.; Khalili, N.; Sahebi, E.; Namazi, S.; Karimian, M.S.; Majeed, M.; Sahebkar, A. Antioxidant effects of curcuminoids in patients with type 2 diabetes mellitus: A randomized controlled trial. Inflammopharmacology 2017, 25, 25-31. [CrossRef] [PubMed]

94. Panahi, Y.; Khalili, N.; Sahebi, E.; Namazi, S.; Reiner, Z.; Majeed, M.; Sahebkar, A. Curcuminoids modify lipid profile in type 2 diabetes mellitus: A randomized controlled trial. Complementary Ther. Med. 2017, 33, 1-5. [CrossRef]

95. Rahimnia, A.R.; Panahi, Y.; Alishiri, G.; Sharafi, M.; Sahebkar, A. Impact of supplementation with curcuminoids on systemic inflammation in patients with knee osteoarthritis: Findings from a randomized double-blind placebo-controlled trial. Drug Res. 2015, 65, 521-525. [CrossRef] [PubMed]

96. Nageswari, A.D.; Rajanandh, M.G.; Uday, M.K.R.A.; Nasreen, R.J.; Pujitha, R.R.; Prathiksha, G. Effect of rifampin with bioenhancer in the treatment of newly diagnosed sputum positive pulmonary tuberculosis patients: A double-center study. J. Clin. Tuberc. Other. Mycobact. Dis. 2018, 12, 73-77. [CrossRef]

97. Patel, N.; Jagannath, K.; Vora, A.; Patel, M.; Patel, A. A randomized, controlled, phase III clinical trial to evaluate the efficacy and tolerability of risorine with conventional rifampicin in the treatment of newly diagnosed pulmonary tuberculosis patients. $J$. Assoc. Physicians India 2017, 65, 48-54.

98. Esmaily, H.; Sahebkar, A.; Iranshahi, M.; Ganjali, S.; Mohammadi, A.; Ferns, G.; Ghayour-Mobarhan, M. An investigation of the effects of curcumin on anxiety and depression in obese individuals: A randomized controlled trial. Chin. J. Integr. Med. 2015, 21, 332-338. [CrossRef]

99. Khonche, A.; Biglarian, O.; Panahi, Y.; Valizadegan, G.; Soflaei, S.S.; Ghamarchehreh, M.E.; Majeed, M.; Sahebkar, A. Adjunctive therapy with curcumin for peptic ulcer: A randomized controlled trial. Drug Res. 2016, 66, 444-448. [CrossRef] [PubMed]

100. Lieberman, S.; Spahrs, R.; Stanton, A.; Martinez, L.; Grinder, M. Weight loss, body measurements, and compliance: A 12 week total lifestyle intervention pilot study. Altern. Complement. Ther. 2005, 11, 307-313. [CrossRef]

101. Majeed, M.; Vaidyanathan, P.; Kiradi, P.; Lad, P.S.; Vuppala, K.K. A clinical study on iron deficiency anaemia with bioiron. Int. J. Ayurveda Pharma Res. 2016, 4, 18-24.

102. Panahi, Y.; Alishiri, G.H.; Parvin, S.; Sahebkar, A. Mitigation of systemic oxidative stress by curcuminoids in osteoarthritis: Results of a randomized controlled trial. J. Diet. Suppl. 2016, 13, 209-220. [CrossRef]

103. Sharafkhaneh, A.; Lee, J.J.; Liu, D.; Katz, R.; Caraway, N.; Acosta, C.; Wistuba, I.I.; Aggarwal, B.; Dickey, B.; Moghaddam, S.J.; et al. A pilot double-blind, randomized, placebo-controlled trial of curcumin/bioperine for lung cancer chemoprevention in patients with chronic obstructive pulmonary disease. Adv. Lung Cancer 2013, 2, 62-69. [CrossRef]

104. Mirhafez, S.R.; Farimani, A.R.; Gholami, A.; Hooshmand, E.; Tavallaie, S.; Nobakht, M.G.B.F. The effect of curcumin with piperine supplementation on pro-oxidant and antioxidant balance in patients with non-alcoholic fatty liver disease: A randomized, double-blind, placebo-controlled trial. Drug Metab. Pers. Ther. 2019, 34. [CrossRef]

105. Panahi, Y.; Valizadegan, G.; Ahamdi, N.; Ganjali, S.; Majeed, M.; Sahebkar, A. Curcuminoids plus piperine improve nonalcoholic fatty liver disease: A clinical trial. J. Cell. Biochem. 2019, 120, 15989-15996. [CrossRef]

106. Galluccio, F.; Barskova, T.; Cerinic, M.M. Short-term effect of the combination of hyaluronic acid, chondroitin sulfate, and keratin matrix on early symptomatic knee osteoarthritis. Eur. J. Rheumatol. 2015, 2, 106-108. [CrossRef]

107. Hatab, H.M.; Abdel Hamid, F.F.; Soliman, A.F.; Al-Shafie, T.A.; Ismail, Y.M.; El-Houseini, M.E. A combined treatment of curcumin, piperine, and taurine alters the circulating levels of IL-10 and miR-21 in hepatocellular carcinoma patients: A pilot study. J. Gastrointest. Oncol. 2019, 10, 766-776. [CrossRef]

108. Directo, D.; Wong, M.W.H.; Elam, M.L.; Falcone, P.; Osmond, A.; Jo, E. The Effects of a Multi-Ingredient Performance Supplement Combined with Resistance Training on Exercise Volume, Muscular Strength, and Body Composition. Sports 2019, 7, 152. [CrossRef] [PubMed]

109. Saberi-Karimian, M.; Keshvari, M.; Ghayour-Mobarhan, M.; Salehizadeh, L.; Rahmani, S.; Behnam, B.; Jamialahmadi, T.; Asgary, S.; Sahebkar, A. Effects of curcuminoids on inflammatory status in patients with non-alcoholic fatty liver disease: A randomized controlled trial. Complementary Ther. Med. 2020, 49, 102322. [CrossRef]

110. Heidari-Beni, M.; Moravejolahkami, A.R.; Gorgian, P.; Askari, G.; Tarrahi, M.J.; Bahreini-Esfahani, N. Herbal formulation "turmeric extract, black pepper, and ginger" versus Naproxen for chronic knee osteoarthritis: A randomized, double-blind, controlled clinical trial. Phytother. Res. 2020, 34, 2067-2073. [CrossRef] [PubMed]

111. Majeed, M.; Majeed, S.; Nagabhushanam, K. An open-label pilot study on Macumax supplementation for dry-type age-related macular degeneration. J. Med. Food 2021, 24, 551-557. [CrossRef] [PubMed]

112. Pastor, R.F.; Repetto, M.G.; Lairion, F.; Lazarowski, A.; Merelli, A.; Manfredi Carabetti, Z.; Pastor, I.; Pastor, E.; Iermoli, L.V.; Bavasso, C.A.; et al. Supplementation with resveratrol, piperine and alpha-tocopherol decreases chronic inflammation in a cluster of older adults with metabolic syndrome. Nutrients 2020, 12, 3149. [CrossRef]

113. Sousa, D.F.; Araújo, M.F.M.; de Mello, V.D.; Damasceno, M.M.C.; Freitas, R. Cost-effectiveness of passion fruit albedo versus turmeric in the glycemic and lipaemic control of people with type 2 diabetes: Randomized clinical trial. J. Am. Coll. Nutr. 2020, 10,1-10. [CrossRef]

114. Shadnoush, M.; Zahedi, H.; Norouzy, A.; Sahebkar, A.; Sadeghi, O.; Najafi, A.; Hosseini, S.; Qorbani, M.; Ahmadi, A.; Ardehali, S.H.; et al. Effects of supplementation with curcuminoids on serum adipokines in critically ill patients: A randomized double-blind placebo-controlled trial. Phytother. Res. PTR 2020, 34, 3180-3188. [CrossRef] 
115. Ablon, G.; Kogan, S. A six-month, randomized, double-blind, placebo-controlled study evaluating the safety and efficacy of a nutraceutical supplement for promoting hair growth in women with self-perceived thinning hair. J. Drugs Dermatol. 2018, 17, 558-565.

116. Mohajer, A.; Ghayour-Mobarhan, M.; Parizadeh, S.M.R.; Tavallaie, S.; Rajabian, M.; Sahebkar, A. Effects of supplementation with curcuminoids on serum copper and zinc concentrations and superoxide dismutase enzyme activity in obese subjects. Trace Elem. Electrolytes 2014, 32, 16-21. [CrossRef]

117. Andres, S.; Pevny, S.; Ziegenhagen, R.; Bakhiya, N.; Schafer, B.; Hirsch-Ernst, K.I.; Lampen, A. Safety aspects of the use of quercetin as a dietary supplement. Mol. Nutr. Food Res. 2018, 62, 1700447. [CrossRef]

118. Di Pierro, F.; Bressan, A.; Ranaldi, D.; Rapacioli, G.; Giacomelli, L.; Bertuccioli, A. Potential role of bioavailable curcumin in weight loss and omental adipose tissue decrease: Preliminary data of a randomized, controlled trial in overweight people with metabolic syndrome. Preliminary study. Eur. Rev. Med. Pharmacol. Sci. 2015, 19, 4195-4202.

119. Piontek, U.; Wallaschofski, H.; Kastenmuller, G.; Suhre, K.; Volzke, H.; Do, K.T.; Artati, A.; Nauck, M.; Adamski, J.; Friedrich, N.; et al. Sex-specific metabolic profiles of androgens and its main binding protein SHBG in a middle aged population without diabetes. Sci. Rep. 2017, 7, 2235. [CrossRef]

120. Pattanaik, S.; Hota, D.; Prabhakar, S.; Kharbanda, P.; Pandhi, P. Effect of piperine on the steady-state pharmacokinetics of phenytoin in patients with epilepsy. Phytother. Res. PTR 2006, 20, 683-686. [CrossRef]

121. Pattanaik, S.; Hota, D.; Prabhakar, S.; Kharbanda, P.; Pandhi, P. Pharmacokinetic interaction of single dose of piperine with steady-state carbamazepine in epilepsy patients. Phytother. Res. PTR 2009, 23, 1281-1286. [CrossRef]

122. Zutshi, R.K.; Singh, R.; Zutshi, U.; Johri, R.K.; Atal, C.K. Influence of piperine on rifampicin blood levels in patients of pulmonary tuberculosis. J. Assoc. Physicians India 1985, 33, 223-224.

123. Badmaev, V.; Majeed, M.; Norkus, E.P. Piperine, an alkaloid derived from black pepper increases serum response of beta-carotene during 14-days of oral beta-carotene supplementation. Nutr. Res. 1999, 19, 381-388. [CrossRef]

124. Badmaev, V.; Majeed, M.; Prakash, L. Piperine derived from black pepper increases the plasma levels of coenzyme Q10 following oral supplementation. J. Nutr. Biochem. 2000, 11, 109-113. [CrossRef]

125. Shoba, G.; Joy, D.; Joseph, T.; Majeed, M.; Rajendran, R.; Srinivas, P.S. Influence of piperine on the pharmacokinetics of curcumin in animals and human volunteers. Planta Med. 1998, 64, 353-356. [CrossRef]

126. Gupta, S.K.; Velpandian, T.; Sengupta, S.; Mathur, P.; Sapra, P. Influence of piperine on nimesulide induced antinociception. Phytother. Res. PTR 1998, 12, 266-269. [CrossRef]

127. Hiwale, A.R.; Dhuley, J.N.; Naik, S.R. Effect of co-administration of piperine on pharmacokinetics of beta-lactam antibiotics in rats. Indian J. Exp. Biol. 2002, 40, 277-281.

128. Janakiraman, K.; Manavalan, R. Studies on effect of piperine on oral bioavailability of ampicillin and norfloxacin. Afr. J. Tradit. Complementary Altern. Med. AJTCAM 2008, 5, 257-262. [CrossRef]

129. Jin, M.J.; Han, H.K. Effect of piperine, a major component of black pepper, on the intestinal absorption of fexofenadine and its implication on food-drug interaction. J. Food Sci. 2010, 75, H93-H96. [CrossRef]

130. Alhumayyd, M.S.; Bukhari, I.A.; Almotrefi, A.A. Effect of piperine, a major component of black pepper, on the pharmacokinetics of domperidone in rats. J. Physiol. Pharmacol. 2014, 65, 785-789.

131. Veeresham, C.; Sujatha, S.; Rani, T.S. Effect of piperine on the pharmacokinetics and pharmacodynamics of glimepiride in normal and streptozotocin-induced diabetic rats. Nat. Prod. Commun. 2012, 7, 1283-1286. [CrossRef]

132. Auti, P.; Choudhary, A.; Gabhe, S.; Mahadik, K. Bioanalytical method development, validation and its application in pharmacokinetic studies of verapamil in the presence of piperine in rats. Int. J. Pharm. Res. 2018, 10, 118-123.

133. Basu, S.; Jana, S.; Patel, V.B.; Patel, H. Effects of piperine, cinnamic acid and gallic acid on rosuvastatin pharmacokinetics in rats. Phytother. Res. PTR 2013, 27, 1548-1556. [CrossRef]

134. Mujumdar, A.M.; Dhuley, J.N.; Deshmukh, V.K.; Naik, S.R. Effect of piperine on bioavailability of oxyphenylbutazone in rats. Indian Drugs 1999, 36, 123-126.

135. Parveen, B.; Pillai, K.K.; Tamboli, E.T.; Ahmad, S. Effect of piperine on pharmacokinetics of sodium valproate in plasma samples of rats using gas chromatography-mass spectrometry method. J. Pharm. Bioallied Sci. 2015, 7, 317-320. [CrossRef] [PubMed]

136. Suvarna, V.M.; Sangave, P.C. HPLC Estimation, Ex vivo Everted Sac Permeability and In Vivo Pharmacokinetic Studies of Darunavir. J. Chromatogr. Sci. 2018, 56, 307-316. [CrossRef]

137. Auti, P.; Gabhe, S.; Mahadik, K. Bioanalytical method development and its application to pharmacokinetics studies on Simvastatin in the presence of piperine and two of its synthetic derivatives. Drug Dev. Ind. Pharm. 2019, 45, 664-668. [CrossRef] [PubMed]

138. Rewanthwar, S.; Lakshmi, P.K. Effect of piperine, quercetin, polysorbate 80 on the oral bioavailability of losartan in Male Wistar rats. Pharm. Nanotechnol. 2014, 2, 49-55. [CrossRef]

139. Singh, A.; Pawar, V.K.; Jakhmola, V.; Parabia, M.H.; Awasthi, R.; Sharma, G. In vivo assessment of enhanced bioavailability of metronidazole with piperine in rabbits. Res. J. Pharm. Biol. Chem. Sci. 2010, 1, 273-278.

140. Sama, V.; Nadipelli, M.; Yenumula, P.; Bommineni, M.R.; Mullangi, R. Effect of piperine on antihyperglycemic activity and pharmacokinetic profile of nateglinide. Arzneimittel-Forschung 2012, 62, 384-388. [CrossRef] [PubMed]

141. Venkatesh, S.; Durga, K.D.; Padmavathi, Y.; Reddy, B.M.; Mullangi, R. Influence of piperine on ibuprofen induced antinociception and its pharmacokinetics. Arzneimittel-Forschung 2011, 61, 506-509. [CrossRef] 
142. Chauhan, V.B.; Modi, C.M.; Patel, U.D.; Patel, H.B. The effect of piperine pre-conditioning on the pharmacokinetics of orally administered marbofloxacin in rats. Vet. Arh. 2020, 90, 69-75. [CrossRef]

143. Kolakota, R.; Bothsa, A.; Mugada, V. Impact of N-acyl piperidine (Piperine) from Piper nigrum on the pharmacokinetics of CYP3A substrate almotriptan in rats. Trop. J. Nat. Prod. Res. 2020, 4, 378-384. [CrossRef]

144. Tiwari, A.; Gabhe, S.Y.; Mahadik, K.R. Comparative study on the pharmacokinetics of ibuprofen alone or in combination with piperine and its synthetic derivatives as a potential bioenhancer. Int. J. Pharm. Sci. Res. 2021, 12, 363-371. [CrossRef]

145. Mishra, P.S.; Phadnis, P.; Vyas, S.; Nyati, P. Study of cns activities of piperine perse and its bio-enhancing effect on various drugs in experimental animal models. Int. J. Pharm. Pharm. Sci. 2016, 8, 135-140.

146. Atal, S.; Atal, S.; Vyas, S.; Phadnis, P. Bio-enhancing effect of piperine with metformin on lowering blood glucose level in alloxan induced diabetic mice. Pharmacogn. Res. 2016, 8, 56-60. [CrossRef]

147. Qiang, F.; Kang, K.W.; Han, H.K. Repeated dosing of piperine induced gene expression of P-glycoprotein via stimulated pregnane-X-receptor activity and altered pharmacokinetics of diltiazem in rats. Biopharm. Drug Dispos. 2012, 33, 446-454. [CrossRef]

148. Ren, T.; Xiao, M.; Yang, M.; Zhao, J.; Zhang, Y.; Hu, M.; Cheng, Y.; Xu, H.; Zhang, C.; Yan, X.; et al. Reduced systemic and brain exposure with inhibited liver metabolism of carbamazepine after its long-term combination treatment with piperine for epilepsy control in rats. AAPS J. 2019, 21, 90. [CrossRef] [PubMed]

149. Zayed, A.; Babaresh, W.M.; Darweesh, R.S.; El-Elimat, T.; Hawamdeh, S.S. Piperine alters the pharmacokinetics and anticoagulation of warfarin in rats. J. Exp. Pharmacol. 2020, 12, 169-179. [CrossRef]

150. Han, H.K. The effects of black pepper on the intestinal absorption and hepatic metabolism of drugs. Expert Opin. Drug Metab. Toxicol. 2011, 7, 721-729. [CrossRef] [PubMed]

151. EFSA. European Food Safety Authority. Guidance on selected default values to be used by the EFSA Scientific Committee, Scientific Panels and Units in the absence of actual measured data. EFSA J. 2012, 10, 2579. 